\title{
Impacts of Deep Water Structuring on Seabed Pollution Levels: Evidence from Radiogenic Isotopes (Pb-Sr-Nd) in Surface Sediments Along the Reykjanes Ridge (Southern Iceland)
}

\section{Dia Hantchi Karimou,}

Université Dan Dicko Dankoulodo, Faculté des Sciences et Techniques,

UMR-SERMUG, Département de Géologie, Maradi, Niger

Konaté Moussa,

Université Abdou Moumouni, Faculté des Sciences et Techniques,

Laboratoire Eaux Souterraines et Géoressources, Niamey, Niger

\section{Ibrah Landi Ali,}

Université Dan Dicko Dankoulodo, Faculté des Sciences et Techniques,

UMR-SERMUG, Département de Chimie, Maradi, Niger

Stevenson K. Ross,

Gariépy Clément,

Université du Québec à Montréal, GÉOTOP, Montréal, Québec, Canada

Doi: 10.19044/esj.2019.v15n15p505 URL:http://dx.doi.org/10.19044/esj.2019.v15n15p505

\begin{abstract}
Significant proportions of debris containing pollutants are present in remote and unknown areas of the deep seabed. Although identified amongst the top threats to marine ecosystem and human health, the mechanisms that particulate materials entered rapidly these deep ocean systems are still matter of debate. This study use depicting radiogenic isotopes $(\mathrm{Sr}, \mathrm{Nd}, \mathrm{Pb})$ to question the relationship between the seabed sediment contamination levels and ambient stratification in the North Atlantic Ocean. On this basis, we studied sedimentary inputs and related mechanisms from more recent sequences collected at three locations representing different deep-sea hydrodynamics along the Reykjanes Ridge. Sm-Nd concentrations, as well as $\mathrm{Sm}-\mathrm{Nd}-\mathrm{Sr}-\mathrm{Pb}$ isotopic compositions, were determined in digested and purified fraction of the sediment cores by Thermal Ionization Mass Spectrometry (TIMS). The Sm-Nd-Sr-Pb data simply reflect the scale of the perturbation of upper part $(0-15 \mathrm{~cm})$ of the sequences, which is much more pronounced in east flank than crossing and west bordering ridge areas. The $\mathrm{Pb}-\mathrm{Pb}$ systematics show that the intensity of water mass mixing modulates degree of contamination and induced the modal transport of detrital
\end{abstract}


components. As consequence of ambient stratification in this region, two major transport processes of pollutant downwards to the sediments are proposed: (i) sediments entrainment in the eastern flank and over ridge axis primarily dominated by vertical flux of particulates controlled by repackage and dislocation by strong mechanical mixing; and (ii) in the west flank, advection of abyssal waters, due to well-stratified mixing layer, provides particulates from the NEADW1 and DSOW.

Keywords: Reykjanes Ridge, North Atlantic, water stratification, Radiogenic isotopes, seabed pollution

\section{Introduction}

The general circulation of water in the world's oceans is fairly well documented (Talley, 2002; Rahmstorf, 2006; Thompson \& Rahmstorf, 2009; Sarafanov \& al., 2012; Daniault \& al., 2016). In the Atlantic, with water parcels such as the North Atlantic Drift (i.e. the northern prolongation of the Gulf Stream; Manighetti, 2001), thermohaline currents allow a transfer of heat from the equator towards the poles (Kuhlbrodt \& al., 2007; García-Ibáñez \& al., 2018). Northward Iceland, in the Norwegian and Greenland seas, the cooling, sinking, and overturning of the North Atlantic drift give the tropics masses of cold, salty water flowing into mighty "rivers" at the bottom of the ocean (Rattinacannou, 2011; Eldevik \& Nilsen, 2013). Thus, each year, large volumes of particles and particularly anthropogenic debris are transported, reworked and distributed in maritime spaces (Hudson, 2017; Racapé \& al., 2018).

Thanks to its position as a mid-Atlantic dorsal island, Iceland would play a leading role in this Great Global Conveyor Belt, which partially control the climate of the North Atlantic (Curry \& Mauritzen, 2005; Buckley \& Marshall, 2016). While the mid-oceanic ridge of Reykjanes in southern Iceland, by its morphotectonic characteristics, strongly influences the direction, flow and chemistry of the water bodies displaced by this global thermohaline circulation (Dia Hantchi, 2000; Chafik \& al., 2014). Moreover, finestructure and microstructure full-depth vertical profiles collected along the Reykjanes Ridge though the flank is known to have strong turbulent mixing (Ferron \& al., 2014).

To the extent that the oceanic regions affected by turbulent mixing are also conducive to the formation of homogeneous layers capable of maintaining the stratification of the water column (Munk \& Wunsch, 1998), it can be assumed that the internal structure of the water core is matched only by its crucial importance for carried particles nature and diversity in this abyss (Sutton \& al., 2018). Indeed, "a current can carry several bodies of water and the same mass of water can be transported by several currents" (Simon, 2007). 
More fundamentally, it is through the depths occupied by the different bodies of water that many pollutants become attached to the sediments that are deposited in abyssal depths and accumulated progressively in the deepest depths (Van Cauwenberghe \& al., 2013). The major contaminants found in sediment-water boundary (Homoky \& al., 2016) and deep sea benthic fauna (Courtene-Jones \& al., 2017), further "joining other marine stressors (such as climate change, ocean acidification, overfishing and habitat destruction)", include microplastics and co-toxicants (e.g. traces elements and their isotopes).

As changes (quality and quantity), deep-sea sediments are both an answer of mixing rates (stratifying factor) and aging of deep water bodies (Artale \& al., 2018). An understanding of the sediment entrainment modulation is an important tool to investigate the statements on how microscopic particles (source water masses) have been transported from the surface to the bottom of the oceans. By using indirect tracers of currents, such as radiogenic isotopes of $\mathrm{Pb}, \mathrm{Sr}$ and $\mathrm{Nd}$ [see Frank (2002) ; Kirillova (2017) for a review], this study attempts to show the induced effects of the deep and bottom water columns structure on the variability in the degree of contamination in ocean floor sediments. More specifically, it aims : (i) to establish profiles of the isotopic composition ( $\mathrm{Pb}-\mathrm{Sr}-\mathrm{Sm}-\mathrm{Nd})$ of the sediments column from the Reykjanes mid-oceanic ridge segment between $58^{\circ} \mathrm{N}$ and $60^{\circ} \mathrm{N}$, (ii) to consider sources of natural and anthropogenic particulate inputs and (iii) to infer the role of topographic location and the ingredients of the current dynamics along and over the Reykjanes Ridge.

\section{Material and Methods Study Area}

The Reykjanes Ridge is a section of the Mid-Atlantic Ridge (MAR) from $53^{\circ} \mathrm{N}$ to $64^{\circ} \mathrm{N}$ (Figure 1). It is bordered to the northeast by Iceland and, to the southwest, by the fracture zone of Charlie Gibbs. The ridge thus extends for about $1500 \mathrm{~km}$, between the Irminger basins (Figure 1) to the west and Iceland to the east. Its axial zone, whose depth varies from 0 to $2500 \mathrm{~m}$, has an average opening speed of $20 \mathrm{~mm} \operatorname{year}^{-1}$ (DeMets $\&$ al., 2010). The study area, located between latitude $58^{\circ} \mathrm{N}$ and $60^{\circ} \mathrm{N}$, covers the portion of the ridge extending from the southwestern ridge, which is characterized by an axial valley to the northeast where it lacks (Magde \& Smith, 1995).

Since the review of Lucotte \& Hillaire-Marcel (1994), three major bodies of water that dominate the current oceanic circulation in the Reykjanes Ridge region are identified (Figure 1). The first one corresponds to the western branches of the North Atlantic Current (North Atlantic Drift -NAD), derived from temperate latitudes and known as the Irminger Current. The second is a mixing zone between the NAD and the Labrador Sea Water (LSW) 
Intermediate Waters. The third is the North East Atlantic Deep Water (NEADW), also known as Iceland Scotland Overflow Water (ISOW; e.g. Kanzow \& Zenk, 2014).

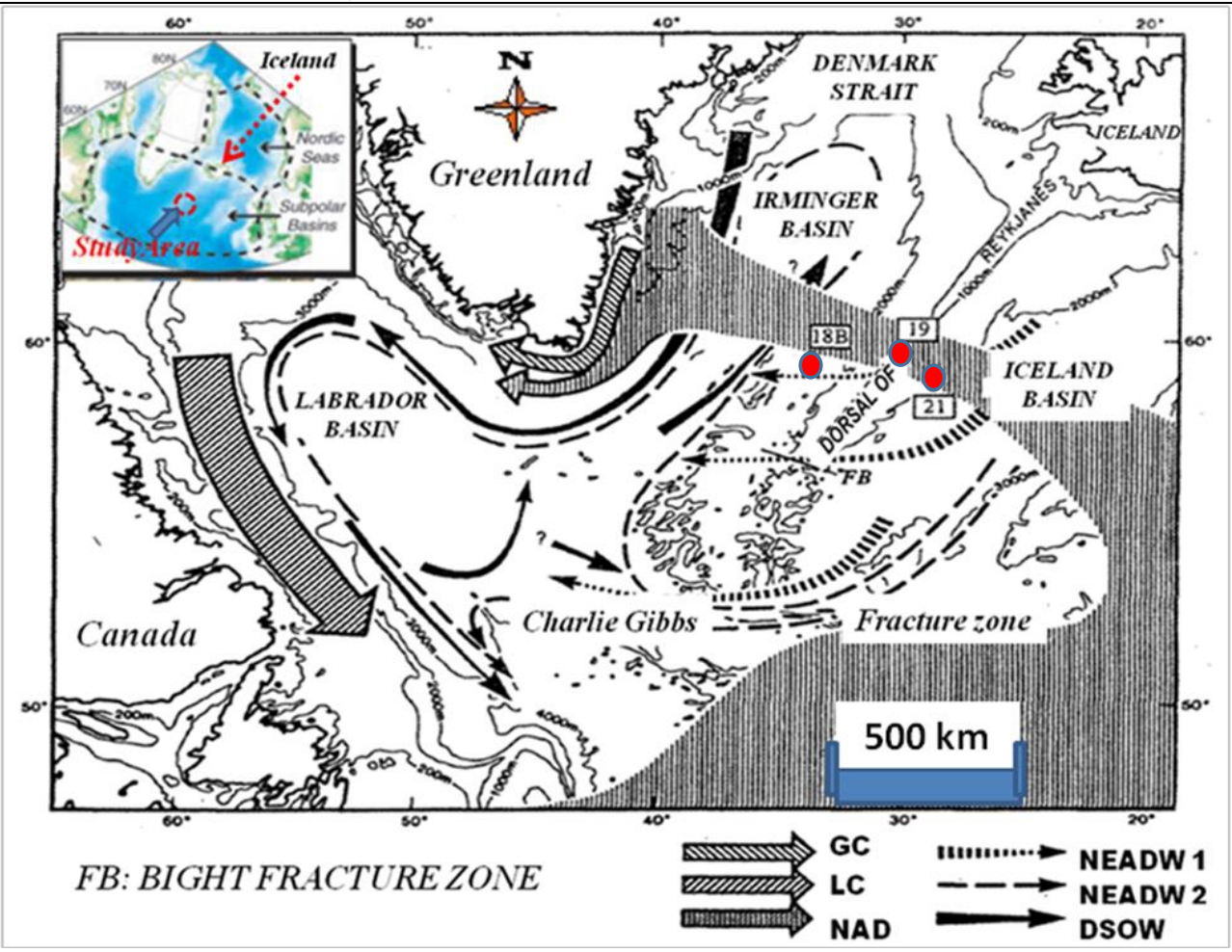

Figure 1: Map of Nordic Seas and Subpolar Basins (Curry \& Mauritzen, 2005) with schematic North Atlantic Thermohaline circulation (Modified from Lucotte \& HillaireMarcel, 1994). Location of the sampled stations (18B, 19 and 21). GC : Greenland Current ; LC : Labrador Current ; NA : North Atlantic Drift ; NEADW : North Atlantic Deep Water ; DSOW : Denmark Strait Overflow Water

The NEADW is composed of waters originating from : (i) the Norwegian Sea, northern part of the Iceland-Faroe Scotia; and (ii) the Rockall Basin, via the Feni Ridge and the Rockall Plateau. Other contributions from the southern Atlantic or even from Antarctica, from the Portuguese coasts and the plains of Biscay have also been reported (Bashmachnikov \& al., 2015). The crossing of the NEADW, from the NE Atlantic to the Irminger Sea, occurs partly freely above the ridge along the major axial discontinuities. This component, identified as the upper sub-unit of the deep-water mass of the Northeast Atlantic, is called NEADW 1. The other part, NEADW 2, would be further forced to pass to the west, in the Irminger Basin, using the area of the Charlie Gibbs fracture (Figure 1). The NEADW1 thus bathes the reliefs of the ridge notably located at less than $2000 \mathrm{~m}$ of depth. On the other hand, the 
NEADW 2, which therefore circulates preferentially along the east and west flanks of the ridge, instead baths the abyssal basins adjacent to the ridge.

In the Northwest Atlantic, these three major water bodies constitute, with the Denmark Strait Overflow Water (DSOW), the bulk of the intermediate waters that form the North Atlantic Deep Water (NADW) that breaks the global ocean (Xu \& al., 2015). According to Våge \& al. (2011), the DSOW is composed not only of the East Greenland Current (EGC), running along the eastern coasts of Greenland, but also of the North Icelandic Jet (NIJ) flowing along Icelandic coasts of the Strait.

\section{Material}

The superficial sediment study was carried out on three box-cores from the three main sites (Figure 1). These stations were chosen because of their geographical position with respect to the ridge. There are station $18 \mathrm{~B}$, on the west flank of the ridge, station 19 located in the axial range and station 21 located on the eastern flank. It will be understood that the basically geographical context of the stations should illustrate the various current and past hydrological and sedimentary conditions in the axial range of the ridge and its adjacent basins (Table 1).

Table 1: Geographical location of investigated sites, box-cores parameters and thickness of sampled deposits

\begin{tabular}{llllllll}
\hline \multicolumn{1}{l}{ Box-core* $^{*}$} & Station & Latitude & Longitude & Depth & Thickness & Context \\
\hline $\begin{array}{l}\text { HU 91 } \\
\text { 060BC }\end{array}$ & $045-$ & $18 \mathrm{~B}$ & $59^{\circ} 40,61 \mathrm{~N}$ & $33^{\circ} 34,9 \mathrm{~W}$ & $2225 \mathrm{~m}$ & $28 \mathrm{~cm}$ & $\begin{array}{l}\text { West Flank } \\
\text { (Irminger basin) }\end{array}$ \\
\hline $\begin{array}{l}\text { HU 91 } \\
\text { 063BC }\end{array}$ & & & & & & & \\
\hline HU 91 & $045-$ & 21 & $59^{\circ} 50,96 \mathrm{~N}$ & $30^{\circ} 20,4 \mathrm{~W}$ & $1319 \mathrm{~m}$ & $35 \mathrm{~cm}$ & Axial Domain \\
071BC & & & & & & \\
\hline
\end{tabular}

* Hereafter $060 B C, 063 B C$ and $071 B C$

In addition, the per-box drilling technique results in minimal disturbance of the sediment and allows recovery of the summit edge of the deposits. The sediments supply consist essentially of siliceous-rich clays, sponge spicules and biogenic carbonates with sand and gravel in varying proportions, as well as many fragments of basalt (Figure 2).

\section{Analytical Methods}

Samples of sediment from the three cores were subjected to isotopic analyzes of $\mathrm{Pb}$ using a 1 to $2 \mathrm{~cm}$ sampling mesh. For the two other isotopic tracers ( $\mathrm{Sr}$ and the Sm-Nd pair), only samples coinciding with the minima and maxima of the $\mathrm{Pb}$ profiles were analyzed. This is worth recalling for reason that there must have been a positive variation between $\mathrm{Pb}$ and $\mathrm{Sr}$ and negative between $\mathrm{Pb}$ and $\mathrm{Nd}$. The analytical results of samples for $\mathrm{Pb}, \mathrm{Sr}, \mathrm{Sm}$ and $\mathrm{Nd}$ 
isotopes was carried out in the geochemistry laboratory of the "Universite $d u$ Québec à Montréal" (UQÀM) in the Geochemistry and Geodynamics Research Center (GÉOTOP).

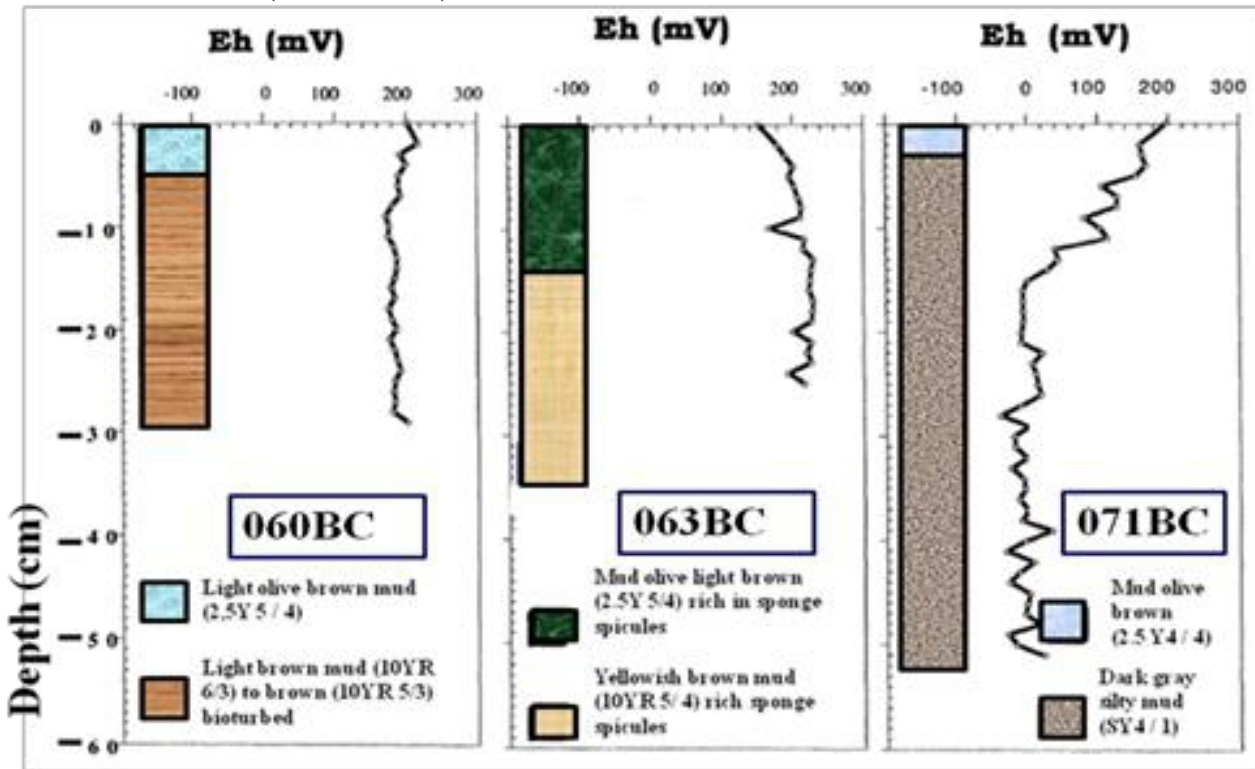

Figure 2: Brief description of surface profiles versus oxidation-reduction potential (Eh) as a function of depth

Analyzes of the isotopes of $\mathrm{Sr}, \mathrm{Nd}, \mathrm{Sm}$ and $\mathrm{Pb}$ contained in the sediments were carried out on the overall non-decarbonated fraction. This allows comparisons between the different tracers and allows the detection of the main trends within the sedimentary sequence. For example, in order to test the insensitivity of neodymium to contamination of seawater, controlled attacks have been attempted on some subsamples of box-cores by partially dissolving the sample using hydrochloric acid $(0.275 \mathrm{~N} \mathrm{HCl}$; Dia Hantchi, 2000). The lead was separated and purified on an ion exchange resin from an aliquot powder solution of 20 to $70 \mathrm{mg}$ of dry sediment. Sr, Nd and Sm are separated and purified from an aliquot powder solution of 70 to $100 \mathrm{mg}$ of dry sediment.

The purified samples are analyzed by Thermal Ionization Mass Spectrometry (TIMS) using a VG Sector 54 apparatus equipped with a multicollection system.

The $\mathrm{Sr}$ isotopic compositions are measured in dynamic multicollection mode ( 3 cycles/7 collectors), and corrected for mass discrimination using ${ }^{86} \mathrm{Sr} /{ }^{88} \mathrm{Sr}=0.1194$. The average internal accuracy on the ${ }^{87} \mathrm{Sr} /{ }^{86} \mathrm{Sr}$ measurement is $\pm 7 \times 10^{-6}$. NIST SRM 987, with a composition of 0.710245 (Amano \& al., 2013), is used to evaluate external reproducibility. The set of 
measures carried out on this standard during this work gives a NBS 987 value of 0.710270 and a variability of $40 \times 10^{-6}$ to $25 \times 10^{-5}$ for about 25 analyzes.

Measurements of the isotopic composition of $\mathrm{Nd}$ are also performed in dynamic multi-collection mode in the ionic form $\mathrm{Nd}^{+}$, maintaining the ion beam of ${ }^{144} \mathrm{Nd}$ at an intensity of the order of 2 to $4 \times 10^{-12} \mathrm{~A}$. The ratios ${ }^{143} \mathrm{Nd} /{ }^{144} \mathrm{Nd}$ are corrected for the effects of mass fractionation by normalization at the natural ratio ${ }^{146} \mathrm{Nd} /{ }^{144} \mathrm{Nd}=0.7219$. However, external reproducibility was quantified by repeated measurements of the La Jolla reference standard. The 17 determinations of this standard, carried out during this study, give a ratio of ${ }^{143} \mathrm{Nd} /{ }^{144} \mathrm{Nd}$ of 0.511846 and a variability of $0.000021(2 \sigma)$. Given the small variations in the natural ${ }^{143} \mathrm{Nd} /{ }^{144} \mathrm{Nd}$ ratios, the measured values of the samples are generally expressed as units $\varepsilon$, where: $\varepsilon_{\mathrm{Nd}}$ $(0)=\left[\left({ }^{143} \mathrm{Nd} /{ }^{144} \mathrm{Nd}\right.\right.$ measured $\left.\left./ 0.512638\right)-1\right] \times 10^{4}$. The unit $\varepsilon$ represents the deviation of the ${ }^{143} \mathrm{Nd} /{ }^{144} \mathrm{Nd}$ of the sample from the value of the Chondritic Uniform Reservoir (CHUR), the present value of which is estimated at 0.512638 (Zeng \& al., 2015). Measurements of Sm and $\mathrm{Nd}$ concentrations as well as calculations of the isotopic ratios of $\mathrm{Sm}$ in the static mode were also carried out in order to validate the correlation between $\mathrm{Sm}$ and $\mathrm{Nd}$.

Lead data collection is performed using a multi-collection routine in static mode. Between 4 and 6 blocks, each containing $15{ }^{206} \mathrm{~Pb} /{ }^{204} \mathrm{~Pb}$, ${ }^{207} \mathrm{~Pb} /{ }^{204} \mathrm{~Pb},{ }^{208} \mathrm{~Pb} /{ }^{204} \mathrm{~Pb},{ }^{206} \mathrm{~Pb} /{ }^{207} \mathrm{~Pb}$ and ${ }^{208} \mathrm{~Pb} /{ }^{206} \mathrm{~Pb}$ ratios are recorded between temperatures of circa $1350{ }^{\circ} \mathrm{C}$ to $1500{ }^{\circ} \mathrm{C}$, controlled using an optical pyrometer. This temperature range makes it possible to carry out all analyzes under the same conditions, ensuring a correction for instrumental mass discrimination of the order of $0.09 \pm 0.02 \%$ per atomic mass. The magnitude of this correction was established by repeated analyzes of NIST SRM 981.

\section{Results}

\section{Box-core HU 91-045-071BC}

In Figure 3, the isotopic compositions of $\mathrm{Pb}(\mathrm{a}), \mathrm{Sr}(\mathrm{b})$ and $\mathrm{Nd}$ (c) are plotted as a function of the depth under the water-sediments interface. This profile of the eastern flank of the ridge, which is $54 \mathrm{~cm}$ deep, reveals the following general characteristics:

- The lower sediments range, between 15 and $50 \mathrm{~cm}$ below the surface, yields relatively constant ${ }^{206} \mathrm{~Pb} /{ }^{204} \mathrm{~Pb}(\sim 19.10)$ ratios (Figure $\left.3 \mathrm{a}\right)$. The uppermost deposits, between 0 and $15 \mathrm{~cm}$, are marked by a steady decrease in the $\mathrm{Pb}\left({ }^{206} \mathrm{~Pb} /{ }^{204} \mathrm{~Pb}\right)$ isotopic composition which becomes less and less radiogenic towards the water-sediments interface $\left({ }^{206} \mathrm{~Pb} /{ }^{204} \mathrm{~Pb} \sim 19.10\right.$ to 18.60$)$.

- The Sr isotopic compositions of the total fraction (Figure 3b) show a systematic variation corresponding to that of $\mathrm{Pb}$; the lowest value $\left({ }^{87} \mathrm{Sr} /{ }^{86} \mathrm{Sr}=0.708889 \pm 14\right.$; Table 2$)$ is therefore found in the surface 
levels. The ${ }^{87} \mathrm{Sr} /{ }^{86} \mathrm{Sr}$ of the total fraction (range $0.708889 \pm 14$ to $0.709024 \pm 09$ ) and the detrital (range $0.708080 \pm 09$ to $0.708868 \pm 11$ ) is, globally, lower than that of modern seawater (i.e. 0.70920). The leachates yield a ${ }^{87} \mathrm{Sr} /{ }^{86} \mathrm{Sr}$ ratio ranging from $0.709190 \pm 12$ to 0.709225 \pm 09 (Table 2). These values are close to the present seawater composition (Figure 3b).

- $\quad$ The values $\varepsilon_{\varepsilon N d}(0)$ of the bulk sample (Figure $3 \mathrm{c}$ ) are between -1.3 and +3.5 (Table 2). The single sample of the basal zone has the lowest $\mathrm{Nd}$ composition [ $[\mathrm{Nd}(0)=-1.3$ ]. Maximum values [ $[\mathrm{Nd}(0)$ of -0.5 and +3.5 ] are reached at the two measuring points in the top zone $(0-15 \mathrm{~cm})$.

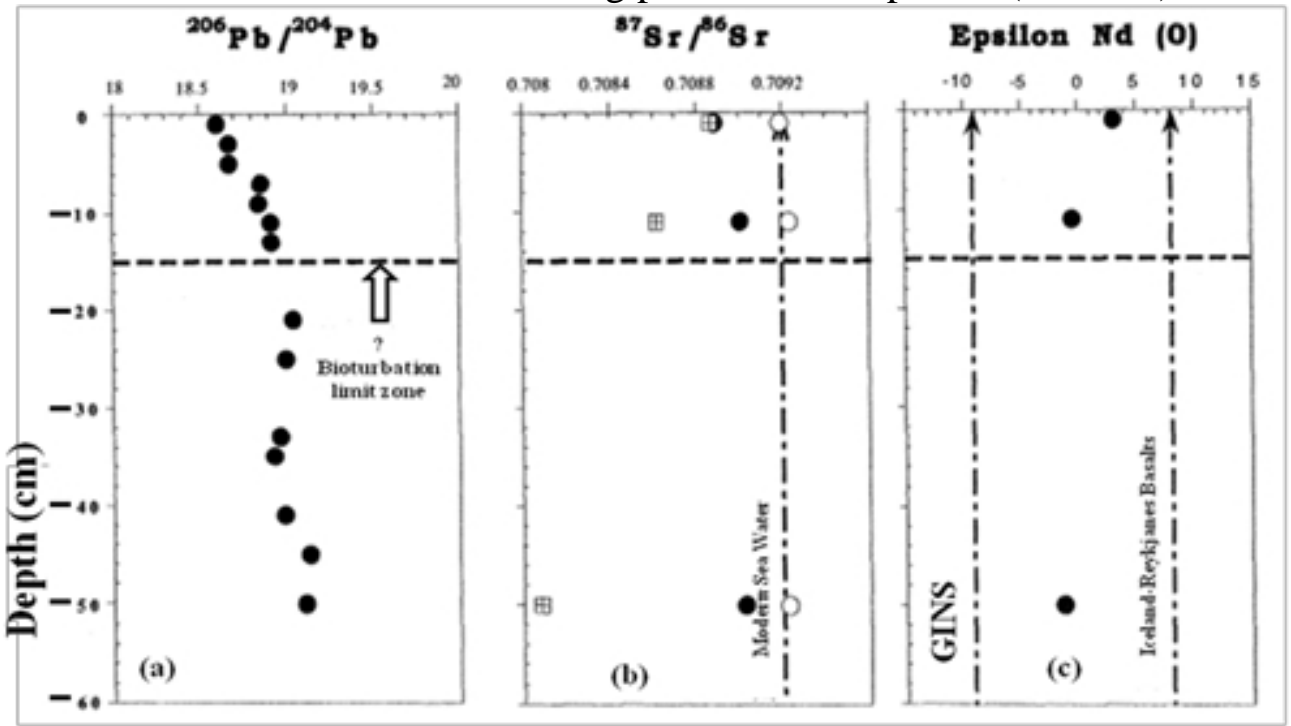

Figure 3: Diagram showing, as a function of depth under the water-sediments interface, the ${ }^{206} \mathrm{~Pb} /{ }^{204} \mathrm{~Pb}$ (a) ratios, ${ }^{87} \mathrm{Sr} /{ }^{86} \mathrm{Sr}(\mathrm{b})$ and the $\varepsilon_{\mathrm{Nd}}(0)$ (c) values of box-core sediments in the eastern flank of the ridge (HU 91-045-071BC). The solid circle corresponds to the total sediment sample, the empty circle to the same sample washed with $0.275 \mathrm{~N} \mathrm{HCl}$ and the square symbol with a cross represents the solid residual fraction of the sediment. Horizontal and vertical dashes return respectively at the limit of the current bioturbation zone and at the isotopic poles: GINS [Greenland-Iceland-Norway Seas : $\varepsilon_{\mathrm{Nd}}(0)=-9$; Goldstein \& Hemming, 2003], MORB Iceland-Reykjanes [ $\varepsilon_{\mathrm{Nd}}(0)=+8$; Dia Hantchi, 2000], and Modern seawater $\left({ }^{87} \mathrm{Sr} /{ }^{86} \mathrm{Sr}=0.70920\right.$; e.g. Kirillova, 2017).

The mean values of $\mathrm{Sm}$ and $\mathrm{Nd}$ contents of the total and residual fractions are in the ranges of 4-5 ppm and 17-22 ppm (Table 2), respectively. The ${ }^{147} \mathrm{Sm} /{ }^{144} \mathrm{Nd}$ values show a similar spread in the total and residual fractions (mean value of 0.141). While, the $\mathrm{T}_{\mathrm{DM}}(\mathrm{Ma})$ values go from 919 in the total fraction to 702 in the residual (Table 2). 
Table 2: ${ }^{87} \mathrm{Sr} /{ }^{86} \mathrm{Sr}$ ratios, $\mathrm{Sm}-\mathrm{Nd}$ composition and concentration data, and model ages $\left(\mathrm{T}_{\mathrm{DM}}\right)$ for the three box-cores

\begin{tabular}{|c|c|c|c|c|c|c|}
\hline Sample & ${ }^{87} \mathrm{Sr} /{ }^{86} \mathrm{Sr}$ & $\boldsymbol{\varepsilon}_{\mathrm{Nd}}(\mathbf{0}$ & $\begin{array}{l}\text { Sm } \\
\text { (ppm } \\
\text { ) }\end{array}$ & $\begin{array}{l}\text { Nd } \\
(\mathbf{p p m})\end{array}$ & $\begin{array}{l}{ }^{147} \mathrm{Sm} / \\
{ }^{144} \mathrm{Nd}\end{array}$ & $\begin{array}{l}\mathbf{T}_{\mathrm{DM}^{*}} \\
\text { (Ma) }\end{array}$ \\
\hline \multicolumn{7}{|l|}{ HU 91 045-071BC } \\
\hline $\begin{array}{l}\text { 0-2 cm Total } \\
0-2 \mathrm{~cm} \text { Residual } \\
0-2 \mathrm{~cm} \text { Leachate }\end{array}$ & $\begin{array}{l}\mathbf{0 . 7 0 8 8 8 9} \pm \mathbf{1 4} \\
0.708868 \pm 11 \\
0.709190 \pm 12\end{array}$ & $\begin{array}{l}\mathbf{+ 3 . 1} \\
+1.6\end{array}$ & $\begin{array}{l}3.77 \\
5.62\end{array}$ & $\begin{array}{l}\mathbf{1 6 . 1 9} \\
24.11\end{array}$ & $\begin{array}{l}\mathbf{0 . 1 4 1} \\
0.141\end{array}$ & $\begin{array}{l}854 \\
696\end{array}$ \\
\hline $\begin{array}{l}\mathbf{1 0 - 1 2} \mathrm{cm} \text { Total } \\
10-12 \mathrm{~cm} \text { Residual } \\
10-12 \mathrm{~cm} \text { Leachate }\end{array}$ & $\begin{array}{l}\mathbf{0 . 7 0 9 0 0 8} \pm \mathbf{1 1} \\
0.708617 \pm 11 \\
0.709233 \pm 09 \\
\end{array}$ & $\begin{array}{l}\mathbf{- 0 . 5} \\
+2.5\end{array}$ & $\begin{array}{l}3.99 \\
4.99\end{array}$ & $\begin{array}{l}\mathbf{1 7 . 1 5} \\
21.42\end{array}$ & $\begin{array}{l}\mathbf{0 . 1 4 1} \\
0.141\end{array}$ & $\begin{array}{l}909 \\
598\end{array}$ \\
\hline $\begin{array}{l}48-50 \mathrm{~cm} \text { Total } \\
48-50 \mathrm{~cm} \text { Residual } \\
48-50 \mathrm{~cm} \text { Leachate }\end{array}$ & $\begin{array}{l}\mathbf{0 . 7 0 9 0 2 4} \pm \mathbf{0 9} \\
0.708080 \pm 09 \\
0.709225 \pm 09\end{array}$ & $\begin{array}{l}-\mathbf{- 1 . 3} \\
+0.5\end{array}$ & $\begin{array}{l}3.91 \\
4.66\end{array}$ & $\begin{array}{l}\mathbf{1 6 . 7 8} \\
19.77\end{array}$ & $\begin{array}{l}\mathbf{0 . 1 4 1} \\
0.142\end{array}$ & $\begin{array}{l}994 \\
812\end{array}$ \\
\hline $\begin{array}{l}\text { Mean Total fraction } \\
\text { Mean Residual fraction }\end{array}$ & & $\begin{array}{l}\mathbf{+ 0 . 4} \\
+1.5 \\
\end{array}$ & $\begin{array}{l}4 \\
5\end{array}$ & $\begin{array}{l}17 \\
22\end{array}$ & $\begin{array}{l}\mathbf{0 . 1 4 1} \\
0.141\end{array}$ & $\begin{array}{l}919 \\
702\end{array}$ \\
\hline \multicolumn{7}{|l|}{ HU 91 045-063BC } \\
\hline $\begin{array}{l}0-2 \text { cm Total } \\
0-2 \mathrm{~cm} \text { Residual } \\
0-2 \mathrm{~cm} \text { Leachate }\end{array}$ & $\begin{array}{l}\mathbf{0 . 7 0 9 0 1 7} \pm \mathbf{1 1} \\
0.708911 \pm 08 \\
0.709184 \pm 14\end{array}$ & $\begin{array}{l}-1.3 \\
-0.3\end{array}$ & $\begin{array}{l}3.39 \\
4.58\end{array}$ & $\begin{array}{l}\mathbf{1 3 . 1 0} \\
19.95\end{array}$ & $\begin{array}{l}0.156 \\
0.139\end{array}$ & $\begin{array}{l}\mathbf{1 2 4 3} \\
889\end{array}$ \\
\hline $\begin{array}{l}\mathbf{1 0 - 1 2} \mathbf{c m} \text { Total } \\
10-12 \mathrm{~cm} \text { Residual }\end{array}$ & $\begin{array}{l}\mathbf{0 . 7 0 9 0 7 0} \pm \mathbf{1 1} \\
0.709011 \pm 09\end{array}$ & $\begin{array}{l}-1.2 \\
-1.0\end{array}$ & $\begin{array}{l}2.81 \\
3.51\end{array}$ & $\begin{array}{l}\mathbf{1 2 . 0 8} \\
15.35\end{array}$ & $\begin{array}{l}0.141 \\
0.138\end{array}$ & $\begin{array}{l}982 \\
897\end{array}$ \\
\hline $\begin{array}{l}\mathbf{3 2 - 3 4} \text { cm Total } \\
32-34 \mathrm{~cm} \text { Residual } \\
32-34 \mathrm{~cm} \text { Leachate }\end{array}$ & $\begin{array}{l}\mathbf{0 . 7 0 8 9 8 7} \pm \mathbf{1 2} \\
0.708850 \pm 09 \\
0.709233 \pm 12\end{array}$ & $\begin{array}{l}\mathbf{- 0 . 5} \\
-1.0\end{array}$ & $\begin{array}{l}\mathbf{3 . 0 6} \\
5.40\end{array}$ & $\begin{array}{l}\mathbf{1 3 . 4 0} \\
23.59\end{array}$ & $\begin{array}{l}\mathbf{0 . 1 3 8} \\
0.138\end{array}$ & $\begin{array}{l}872 \\
929\end{array}$ \\
\hline $\begin{array}{l}\text { Mean Total fraction } \\
\text { Mean Residual fraction }\end{array}$ & & $\begin{array}{l}-0.1 \\
-0.1\end{array}$ & $\begin{array}{l}3.1 \\
4.5\end{array}$ & $\begin{array}{l}\mathbf{1 3} \\
20\end{array}$ & $\begin{array}{l}0.145 \\
0.138\end{array}$ & $\begin{array}{l}\mathbf{1 0 3 2} \\
905\end{array}$ \\
\hline
\end{tabular}

HU $91045-060 B C$

\begin{tabular}{|l|l|l|l|l|l|l|}
\hline $\mathbf{0 - 2}$ cm Total & $\mathbf{0 . 7 0 9 2 6 9} \pm \mathbf{1 1}$ & $\mathbf{- 8 . 9}$ & $\mathbf{1 . 7 4}$ & $\mathbf{8 , 1 0}$ & $\mathbf{0 . 1 3 0}$ & $\mathbf{1 5 6 1}$ \\
$0-2$ cm Residual & $0.709215 \pm 08$ & -9.9 & 2.30 & 10.86 & 0.128 & 1621 \\
$0-2$ cm Leachate & $0.709158 \pm l 8$ & & & & & \\
\hline $\mathbf{2 - 4}$ cm Total & $\mathbf{0 . 7 0 9 2 2 9} \pm \mathbf{1 2}$ & $\mathbf{- 9 . 5}$ & $\mathbf{1 . 7 3}$ & $\mathbf{8 . 1 4}$ & $\mathbf{0 . 1 2 8}$ & $\mathbf{1 5 8 3}$ \\
$\mathbf{4 - 6}$ cm Total & $\mathbf{0 . 7 0 9 3 3 2} \pm \mathbf{1 1}$ & $\mathbf{- 1 0 . 0}$ & $\mathbf{1 . 9 9}$ & $\mathbf{9 . 4 4}$ & $\mathbf{0 . 1 2 8}$ & $\mathbf{1 6 2 8}$ \\
$4-6$ cm Residual & $0.709326 \pm l 2$ & & & & & \\
$4-6$ cm Leachate & $0.709183 \pm l 1$ & & & & & \\
\hline $\mathbf{2 4 - 2 6}$ cm Total & $\mathbf{0 . 7 0 9 6 5 2} \pm \mathbf{0 9}$ & $\mathbf{- 1 1 . 0}$ & $\mathbf{3 . 2 6}$ & $\mathbf{1 6 . 1 0}$ & $\mathbf{0 . 1 2 3}$ & $\mathbf{1 6 1 6}$ \\
$24-26$ cm Residual & $0.709996 \pm l 1$ & & & & & \\
$24-26$ cm Leachate & $0.709123 \pm 19$ & & & & & \\
\hline $\begin{array}{l}\text { Mean Total fraction } \\
\text { Mean Residual fraction }\end{array}$ & & $\mathbf{- 9 . 9}$ & $\mathbf{2 . 2 0}$ & $\mathbf{1 0 . 4 0}$ & $\mathbf{0 . 1 2 7}$ & $\mathbf{1 6 0 2}$ \\
\hline * Values used to calculate & & -9.9 & 2.30 & 10.86 & 0.128 & 1621 \\
\hline
\end{tabular}

* Values used to calculate $\mathrm{T}_{\mathrm{DM}}$ are: $\left({ }^{143} \mathrm{Nd} /{ }^{144} \mathrm{Nd}\right)_{\mathrm{DM}}=0.51315$ and $\left({ }^{147} \mathrm{Sm} /{ }^{144} \mathrm{Nd}\right)_{\mathrm{DM}}=0.217$ (De Paolo, 1988).

\section{Box-core HU 91-045-063BC}

The $\mathrm{Pb}$ isotopic composition in the basal part $(33-15 \mathrm{~cm})$ is homogeneous with an average ${ }^{206} \mathrm{~Pb} /{ }^{204} \mathrm{~Pb}$ of 19.20 (Figure $4 \mathrm{a}$ ). To the opposite, the top part of the profile $(15-0 \mathrm{~cm})$ shows steady decrease in the 
${ }^{206} \mathrm{~Pb} /{ }^{204} \mathrm{~Pb}$ ratios (from 19.20 to 18.60 ). The ${ }^{87} \mathrm{Sr} /{ }^{86} \mathrm{Sr}$ values of total and residual fractions show a strong covariation (Figure $4 \mathrm{~b}$ ). It is also noted here that all the ${ }^{87} \mathrm{Sr} /{ }^{86} \mathrm{Sr}$ values of the total (range $0.708987 \pm 12$ to $0.709017 \pm 11$; Table 2) and residual fractions $\left({ }^{87} \mathrm{Sr} /{ }^{86} \mathrm{Sr} \sim 0.708856 \pm 09\right.$ to $\left.0.709011 \pm 09\right)$ are less than the composition given by the leachates $\left({ }^{87} \mathrm{Sr} /{ }^{86} \mathrm{Sr} \sim 0.709184 \pm 14\right.$ to $0.709233 \pm 12$ ) or the modern seawater. The $\varepsilon_{\mathrm{Nd}}(0)$ values (Figure $4 \mathrm{c}$ ) form a compositionally relatively uniform group according to its small range of $\varepsilon_{\mathrm{Nd}}(0)$ ( -1.3 to -0.3 ; average -0.1 ; Table 2 ). The $\mathrm{Sm}$ and $\mathrm{Nd}$ concentrations fluctuate around 3 and $4.5 \mathrm{ppm}$ in the total fraction, respectively, and 13 to $20 \mathrm{ppm}$ in the solid residual fraction. The ${ }^{147} \mathrm{Sm} /{ }^{144} \mathrm{Nd}$ ratios vary from 0.145 in total fraction to 0.138 in the residual, and $\mathrm{T}_{\mathrm{DM}}(\mathrm{Ma})$ from 1032 to 905 , respectively.

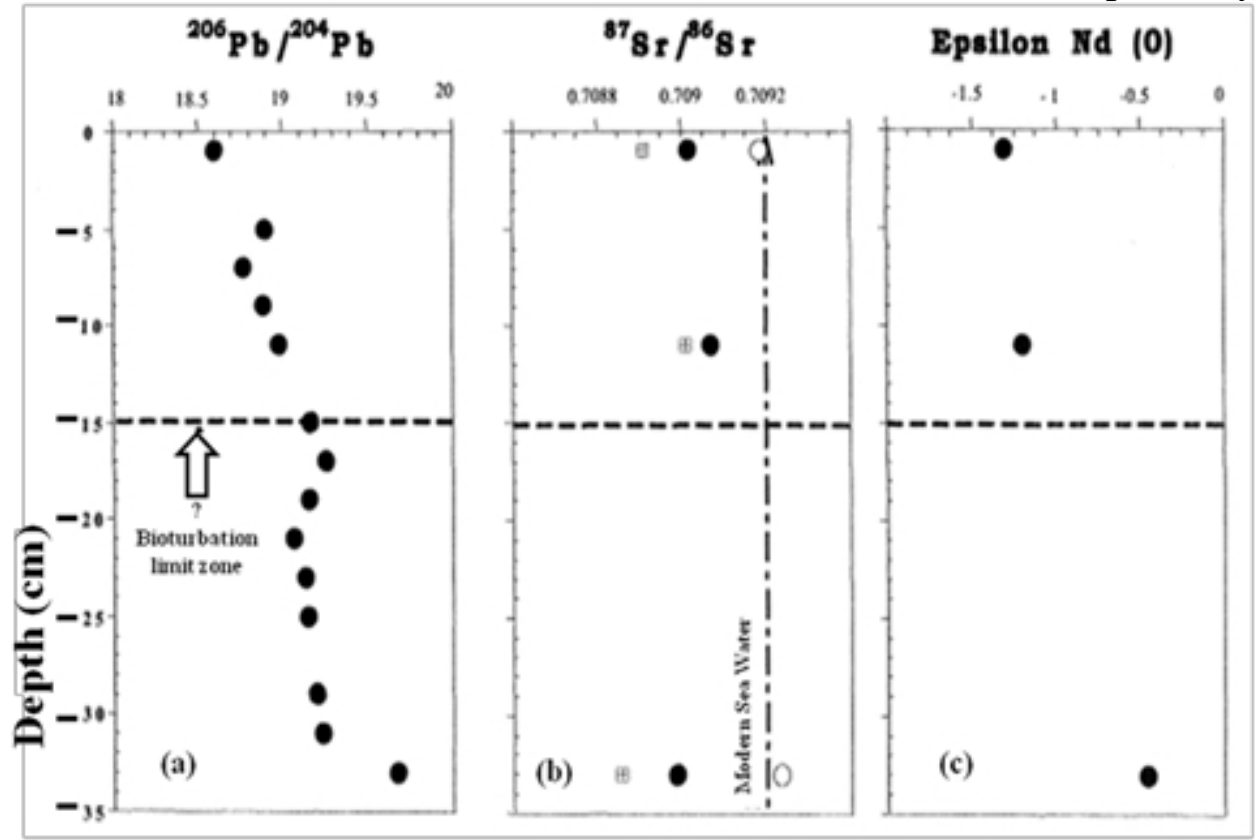

Figure 4: Diagram showing, as a function of depth under the water-sediments interface, the ${ }^{206} \mathrm{~Pb} /{ }^{204} \mathrm{~Pb}$ (a) ratios, ${ }^{87} \mathrm{Sr} /{ }^{86} \mathrm{Sr}(\mathrm{b})$ and the $\varepsilon_{\mathrm{Nd}}(0)$ (c) values of box-core sediments in the axial region of the ridge (HU 91-045-063BC). Same legend and indications as for Figure 3.

\section{Box-core HU 91-045-060BC}

Figure 5 also shows, as a function of depth, the $\mathrm{Pb}, \mathrm{Sr}$ and $\mathrm{Nd}$ compositions of the sediments representative of the western flank of the ridge. This $25 \mathrm{~cm}$ deep profile shows :

- A variation in compositions restricted to a slice of not more than $5 \mathrm{~cm}$ below water-sediments interface.

- A main trend showing a slightly decreasing $\mathrm{Pb}$ isotopic composition $\left({ }^{206} \mathrm{~Pb} /{ }^{204} \mathrm{~Pb}\right.$ from 19.23 to 18.82$)$ with decreasing depth under watersediments interface (Figure 5a). 
- $\quad \mathrm{A}^{87} \mathrm{Sr} /{ }^{86} \mathrm{Sr}$ of total (range $0.709269 \pm 11$ to $0.709652 \pm 09$ ) and residual (from $0.709215 \pm 08$ up to $0.709996 \pm 11$ ) fractions on average above the value of modern seawater (Figure 5b; Table 2).

- $\quad$ A Nd isotope composition plotting between NADW $\left[\varepsilon_{\mathrm{Nd}}(0):-13.5\right]$ and the mean GINS [ $\left.\varepsilon_{\mathrm{Nd}}(0):-9\right]$. Hence, the $\varepsilon_{\mathrm{Nd}}(0)$ values vary around an average of -10.5 in the $25-5 \mathrm{~cm}$. Then, in the $5-0 \mathrm{~cm}$, three samples define a trend with $\varepsilon_{\mathrm{Nd}}(0)$ values increasing ( -10 to -8.9$)$ with decreasing depth under water-sediments interface (Figure 5c).

- $\quad$ Lower Sm and Nd contents (respectively $\sim 2$ and $\sim 10 \mathrm{ppm}$ ) and isotope ratios $\left({ }^{147} \mathrm{Sm} /{ }^{144} \mathrm{Nd} \sim 0.127\right.$; Table 2$)$.

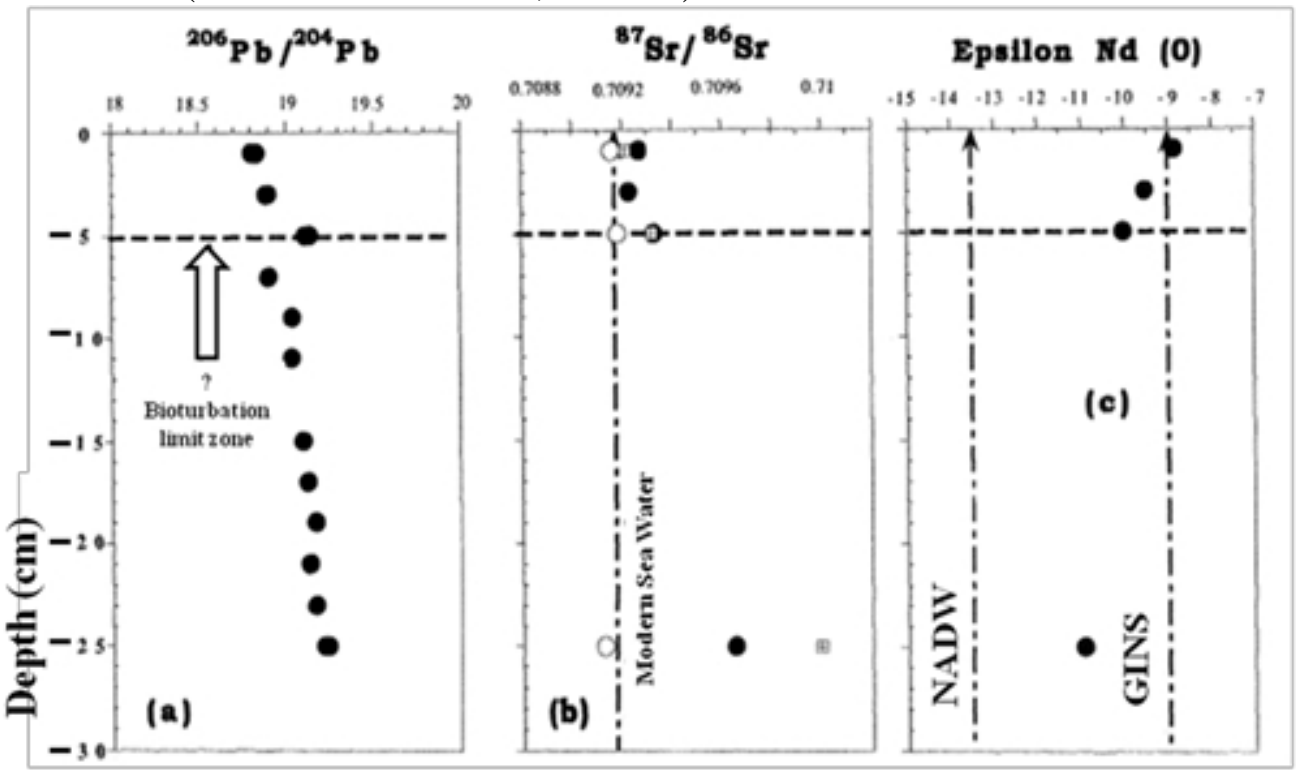

Figure 5: Diagram showing, as a function of depth under the water-sediments interface, the $\mathrm{Pb}(\mathrm{a}), \mathrm{Sr}(\mathrm{b})$, and $\mathrm{Nd}$ isotopic (c) data box-core sediments in the western flank of the ridge (HU 91-045-060BC). The same legend as for Figure 3, with NADW (-13.5; Lacan \& Jeandel, 2005). 


\section{Discussion}

The results obtained on surface sediments show that:

- In all three profiles, the transition between the basal and the summit is variable and seems to be reducible to lithological variations and more oxidation-reduction potential (Eh; see Figure 2).

- In the basal unit, the inputs of detrital $\mathrm{Pb}$ and dissolved $\mathrm{Pb}$ remained very similar throughout the period when this slice had accumulated, or that the composition of the sediment was homogenized as it accumulated through processes of bioturbation.

- The top slices of the profiles show significant variations of $\mathrm{Pb}$ $\left({ }^{206} \mathrm{~Pb} /{ }^{204} \mathrm{~Pb}\right)$ isotopic compositions, as well as for the few samples of $\mathrm{Sr}$, $\mathrm{Sm}$ and $\mathrm{Nd}$ selected at critical levels. These variations are also in agreement with some exceptions, with those of other isotopic ratios $\mathrm{Pb}$ $\left({ }^{207} \mathrm{~Pb} /{ }^{204} \mathrm{~Pb},{ }^{208} \mathrm{~Pb} /{ }^{204} \mathrm{~Pb}\right.$ and most preferably ${ }^{206} \mathrm{~Pb} /{ }^{207} \mathrm{~Pb}$; Figure 6).

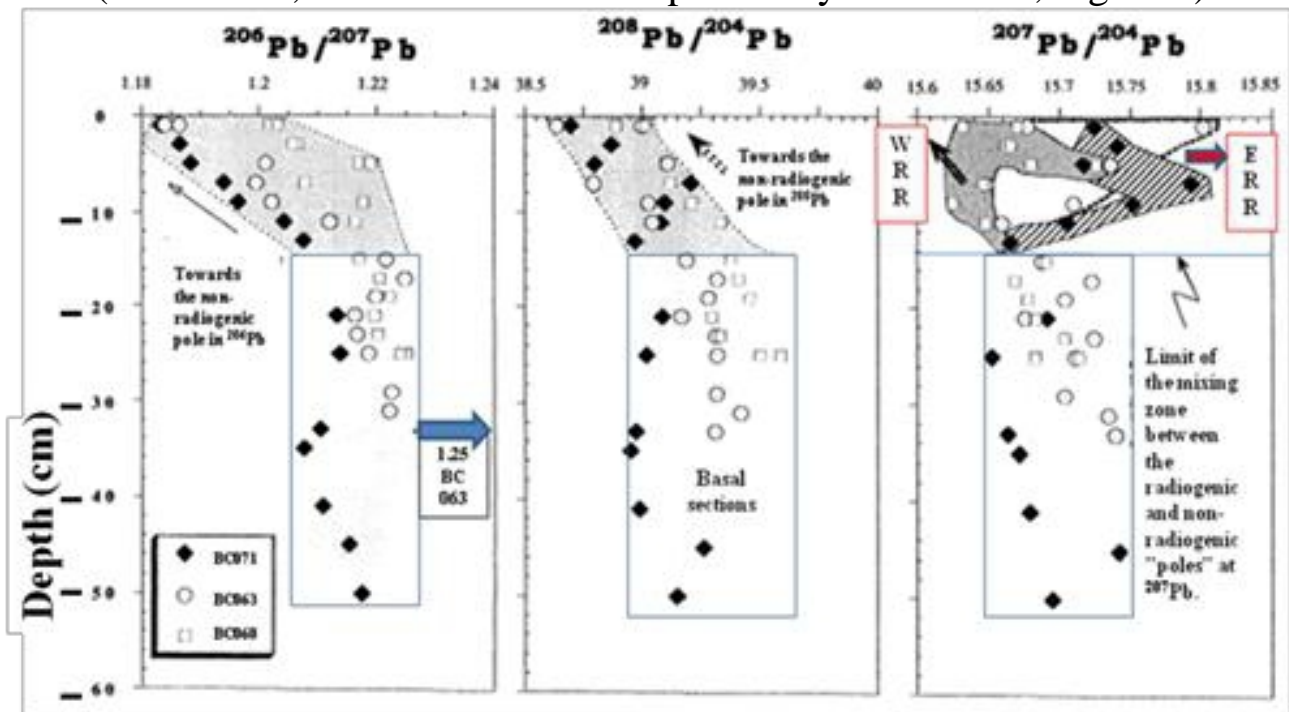

Figure 6: Variations of the ${ }^{206} \mathrm{~Pb} /{ }^{207} \mathrm{~Pb},{ }^{208} \mathrm{~Pb} /{ }^{204} \mathrm{~Pb}$ and ${ }^{207} \mathrm{~Pb} /{ }^{204} \mathrm{~Pb}$ ratios as a function of depth in box-cored sediments. The vertical band corresponds to the basal section of the profiles. WRR: Western Reykjanes Ridge;

ERR : Eastern Reykjanes Ridge.

- The soluble fraction resulting from the $\mathrm{HC} 1$ attack affects, but too little, the isotopic compositions of $\mathrm{Sm}, \mathrm{Nd}$ and $\mathrm{Pb}$ (Table 2). On the other hand, a dilution factor of 1 for $\mathrm{Sm}$ and 5 for $\mathrm{Nd}$ would affect the delivered contents by the total fraction of the sediments but without, however, masking the specific character associated with each of the sequences analyzed. For the purpose of characterizing general trends, within the sedimentary sequence, the results obtained on the total fraction should be acceptable. 


\section{Sm-Nd-Sr isotope ratios: sources areas and process of mixing materials}

The marked and synchronous variations of the isotopic compositions of $\mathrm{Pb}$ and $\mathrm{Sr}(v s \mathrm{Nd})$ in slices of a few centimeters below the water-sediments interface indicate the presence, in varying amounts, of a low radiogenic pole in $\mathrm{Pb}$ and $\mathrm{Sr}$ at the level of recent sedimentation. The spatiotemporal arrangement of $\varepsilon_{\mathrm{Nd}}(0)$ values used as an index of differentiation of deep water masses (Goldstein \& Hemming, 2003) and the drop in Sm and Nd levels show the major role played by the southward water flows from Iceland toward the Reykjanes Ridge. The differences observed in $\mathrm{Nd}$ sediments composition could thus be attributed to a decrease (or as the expression of a remoteness from the source zones) of the detrital particulate load in $\mathrm{Nd}$ of bottom water bodies during course (Lacan \& Jeandel, 2005). However the slight variations, observed in the profile of the core-box from the backbone 063BC (Figure 4c), reveal the complexity of the control of the registration of signatures of deep waters bodies. A likely origin of the non-radiogenic detrital elements in $\mathrm{Pb}$ and $\mathrm{Sr}$ observed in the sediments cannot thus be interpreted simply by the contribution of distal Icelandic sources, such as suggests the elementary " raw " contents of the source regions. Other additional factors therefore play a role in explaining isotopic fluctuations.

\section{The importance of axial topography}

According to some acoustic data in the axial range of the backbone, between $59^{\circ}$ and $60^{\circ} \mathrm{N}$ (Lackschewitz \& al., 1996), we could associate the low variability of the $\mathrm{Nd}$ isotopic composition to the alignment of the stepped fractures that delineate the axial zone, thereby forcing the deep currents to be transited in a direction parallel to the axis. In this case, the quasi-permanent leaching of the rift volcanic formations would suffice to explain the small variations in the $\mathrm{Nd}$ compositions of the 063BC sediments.

The addition of the contribution of the rift would thus constitute the lateral counter-flux fed by the distal contributions. The isotopic and geochemical characteristics attributed to the juvenile radiogenic component in $\mathrm{Nd}$ may therefore be subject to different interpretations with respect to the number of data obtained on the same sequences.

\section{Differential dilution of terrigenous inputs by biogenic carbonates vs. mixing process between mantle and crustal materials}

In the first case, given that the " raw" grades of Sm and $\mathrm{Nd}$ decrease from the eastern sectors to the western flank domain, it is possible that the results obtained are lacking in "representativeness" and that the observed heterogeneity is not apparent. The "raw" contents measured at the three sites would result from a differential dilution of the detrital inputs by the carbonate phase. This dilution would be exacerbated in the sediments of the western 
flank by a greater production of biogenic carbonates in this area. As, the $\mathrm{CaCO}_{3}$ content fluctuates around circa $28-46 \%$ in the eastern flank of the Reykjanes Ridge (Savkina \& al., 2018), circa 10-45 \% along the axial zone and 20-80\% in the western flank of the ridge (Dia Hantchi, 2000).

In another alternative, the "provincialism " of the profiles on both sides of the median rift, as well as the observed heterogeneity between the summit and basal slices, would result from a process of mixing materials of mantle and crustal origin mainland (Figure 7).

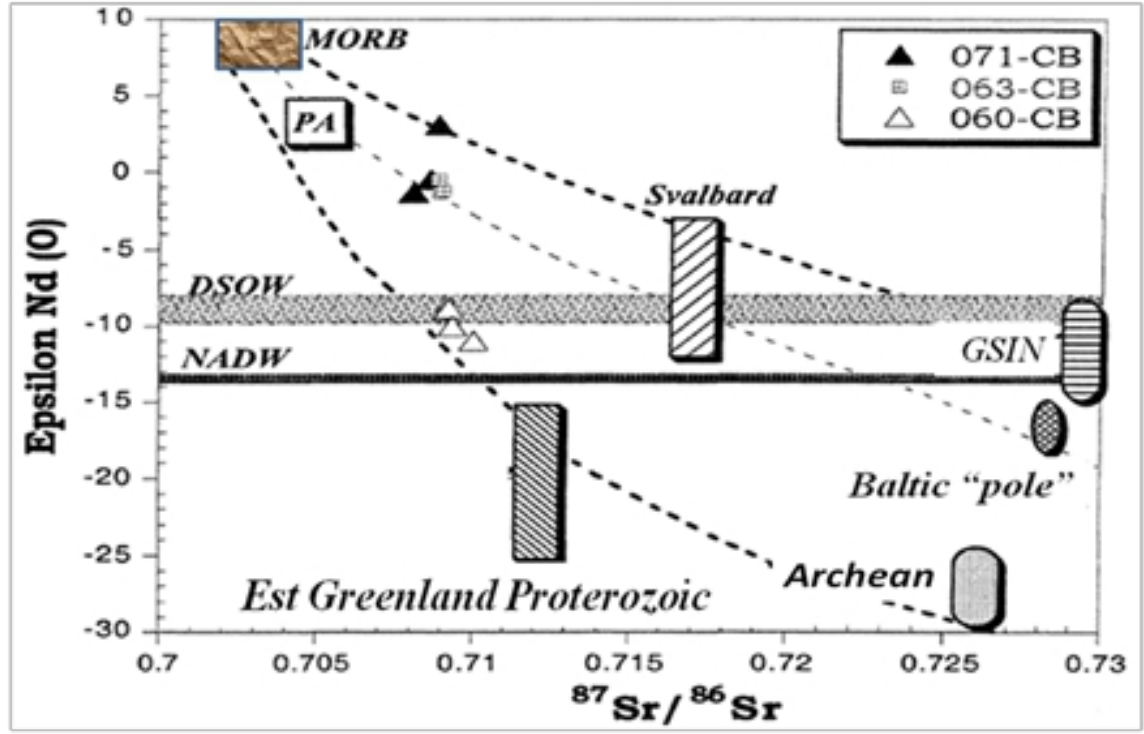

Figure 7: $\mathrm{Sr}-\mathrm{Nd}$ isotopic diagram illustrating the observed variations in surface sediments and other main mantle poles [MORB; PA: Arctic Province and crustal: Archean, Est Greenland Proterozoic, GSIN (New Caledonian of Greenland, Scotland, Ireland and Norway), Svalbard; Dia Hantchi, 2000)], as well as bottom water bodies: NADW and DSOW (Goldstein \& Hemming, 2003; Lacan \& Jeandel, 2005).

The suggestion that the second hypothesis can be put forward to explain the trends observed in the top slices of surface sediments is supported by:

- The consistency of the difference between the absolute $\mathrm{Sm}$ and $\mathrm{Nd}$ concentrations of the total and residual fractions of the sediment (Tables $2)$. These include the decreasing ${ }^{147} \mathrm{Sm} /{ }^{144} \mathrm{Nd}$ ratios $(0.141$ to 0.128$)$ as we move from the east flank to the west flank of the Reykjanes Ridge, and conversely an emplacement of the $\mathrm{T}_{\mathrm{DM}}$ model ages (702 Ma to 1621 $\mathrm{Ma})$.

- $\quad$ The correspondence with the average regional rocks (Fagel \& al., 2014), the very existence of a population of tholeiites poor in Light Rare Earth Elements (LREE) in the axial region (Dia Hantchi, 2000). 
- The results of the values $\varepsilon_{\mathrm{Nd}}(0)$ in profiles 071BC, 063BC and 060BC $\left(+0.4,-0.1\right.$ and -10 , respectively) greater than the $\varepsilon_{\mathrm{Nd}}(0)$ of the NADW $(-13.5)$ but lower than the MORB $(+8)$.

\section{Main driving mechanism of the mantle components}

The Reykjanes Ridge is marked by a prominent active volcanism zone of 10-15 km wide around its axis (Rocha, 2017). Whatever the processes of mantle components enrichment are, they are occurring primarily in the form of : (i) sediments resulting from the erosion of Icelandic and/or Reykjanes Ridge basalts, and (ii) likely to give rise to particles of precipitation from hydrothermal fluids. However, the contribution of radiogenic particles resulting from hydrothermal fluids precipitation seems-difficult to admit. Indeed, the only indices of hydrothermal activity reported so far in the region of the Reykjanes Ridge concern the observed Mn anomalies in the vicinity of the Steinahól site at $63^{\circ} 06^{\prime} \mathrm{N}$ (Elders \& Friðleifsson, 2015). In any event, this potential hydrothermal activity, with a very limited distribution, can have little influence on the isotopic composition of the summit slices so continuously over time and space. Especially from the central rift, the possibility of contamination by hydrothermal phenomena must therefore be rejected. On the other hand, it seems to us the basis for interpreting the existence of these isotopic basal and topological heterogeneities and their spatiotemporal evolution in terms of advected additions of sediments resulting from erosion not only of the basalts of Iceland, but also of the recent lava of the ridge.

As can be seen from Figure 8, the sediments of the three box-cores are for the most part located in a domain framed by the Icelandic poles and three acid poles (Arctic, Greenland and Baltic; Dia Hantchi, 2000):

- Thereby samples belonging to the summit slices define a new alignment, can be interpreted as reflecting a process of mixing between differentiated elements of Iceland, the ridge and the clearly dominant Arctic pole.

- The sediment compositions of the superficial horizons of the western flank (060BC) are placed almost on the mixing line defined by the Arctic pole and the lava of the Reykjanes Ridge, suggesting for the Nd of these samples a distinctly dominant contribution of the volcanic series of the rift. In this view it is the strength of NEADW flow from east to west across the ridge rather than the southward flow that governs the trends observed in the top slices of the western flank sediments.

- Thus, in terms of "nominative sources" present in the study area and on the basis of only three surface samples, our results confirm -and also complete- the observations of Fagel $\&$ al. (2002) from $\mathrm{Sm}-\mathrm{Nd}-\mathrm{Pb}$ data on the decarbonated detritic fraction of less than 2 micrometers. 


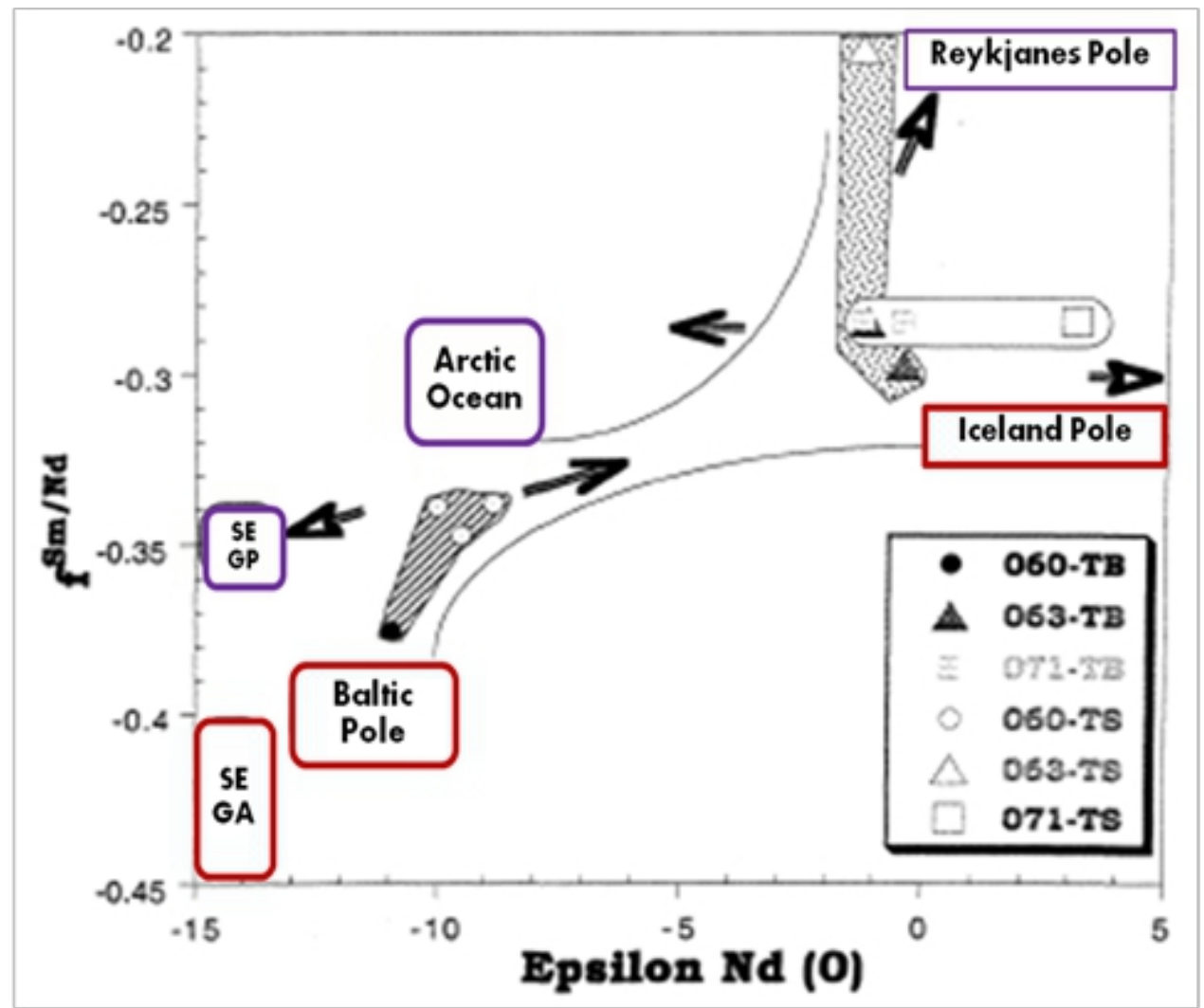

Figure 8: $\mathrm{f}^{\mathrm{Sm} / \mathrm{Nd}}-\varepsilon_{\mathrm{Nd}}(0)$ diagram.

$\mathrm{f}^{\mathrm{Sm} / \mathrm{Nd}}$, denoting the $\mathrm{Sm}-\mathrm{Nd}$ fractionation factor during geologic time with respect to the chondritic uniform reservoir (CHUR), is calculated according to the formula $\mathrm{f}^{\mathrm{Sm} / \mathrm{Nd}}=$ $\left[\left(\left({ }^{147} \mathrm{Sm} /{ }^{144} \mathrm{Nd}\right)\right.\right.$ measured $\left.\left./\left({ }^{147} \mathrm{Sm} /{ }^{144} \mathrm{Nd}\right){ }_{\mathrm{CHUR}}\right)-1\right]$; the current value of CHUR is 0.1677 (DePaolo, 1988). The Mafic (Iceland and Reykjanes Ridge) and felsic (SEGP = SE Greenland Proterozoic; SEGA: SE Greenland Archean; Baltic Inputs; Ocean Arctic) poles are from Dia Hantchi (2000), and Fagel \& al. (2014)

Pb isotope ratios: Prominent anthropogenic component and potentiel links with deep water structuring

The ${ }^{207} \mathrm{~Pb} /{ }^{204} \mathrm{~Pb}$ ratio profiles in the top slices (Figure 6) clearly indicate that highly enriched ${ }^{207} \mathrm{~Pb}$ intakes remain associated with the contribution of ${ }^{206} \mathrm{~Pb} /{ }^{204} \mathrm{~Pb}$ from a less radiogenic source. A " disruptive " or at least anthropogenic particles, especially lead, input via the surface water bodies (Véron \& al., 1994) and atmosphere (Shotyk \& al., 2003) cannot be excluded. Indeed, throughout the region of the Mid-Ocean Ridge of the North Atlantic, since Saunders \& al. (1999) to Ionov \& al. (2002), Kokfelt \& al. (2006), Shorttle \& al. (2013) and Torsvik \& al. (2015), a basalt lavas (even significant crustal contaminated!) has not yet been found which has a ratio of ${ }^{207} \mathrm{~Pb} /{ }^{204} \mathrm{~Pb}$ of more than 15.80 . Comparison of the results with the fields relating to the different samples of basalts from the mid-Atlantic ridge 
between $53^{\circ} \mathrm{N}$ and $80^{\circ} \mathrm{N}$, as well as surface water bodies in the North Atlantic and major atmospheric sources, in the $\mathrm{Pb}-\mathrm{Pb}$ isotope diagrams (Figures $9 \&$ 10) provide the following arguments:

(i) Collectively, the ${ }^{206} \mathrm{~Pb} /{ }^{207} \mathrm{~Pb} v{ }^{208} \mathrm{~Pb} /{ }^{207} \mathrm{~Pb}$ (Figure 9) signature of nonradiogenic inputs of $\mathrm{Pb}$ come from two sources: a mixture of anthropogenic lead and basalts and, more equivocally, of Southeast Greenlandic sources (e.g. Saunders et al., 1999).

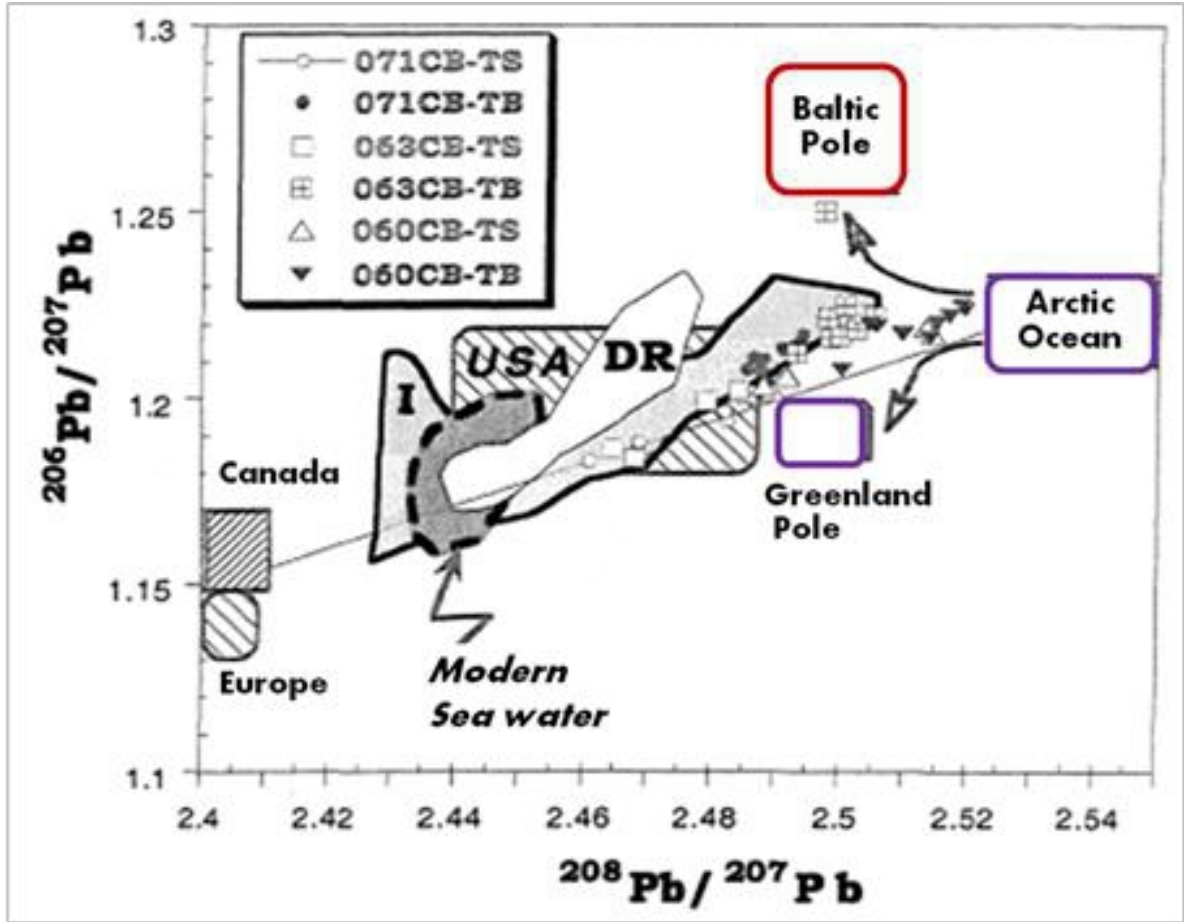

Figure 9: ${ }^{206} \mathrm{~Pb} /{ }^{207} \mathrm{~Pb}$ vs. ${ }^{208} \mathrm{~Pb} /{ }^{207} \mathrm{~Pb}$ diagram of Slice Samples top and basal carrots-boxes. The surface water (Véron \& al., 1994), and Reykjanes Ridge (DR), Iceland (I), Greenlandic medium poles (low value ${ }^{238} \mathrm{U} /{ }^{204} \mathrm{~Pb}=\mu$ ), Arctic ( $\mu$ medium) and Baltic (high value of $\mu$ ) (Dia Hantchi, 2000), as well as U.S.A., Canada and European atmospheric lead (Rosman \& al., 1998) are shown for comparison. TS = top slice and TB = bottom slice. Note that the influence of the Greenlandic pole is translated here by a displacement of the points towards compositions enriched in ${ }^{208} \mathrm{~Pb}$ for low reports ${ }^{206} \mathrm{~Pb} /{ }^{207} \mathrm{~Pb}$.

(ii) The most prominent feature of the ${ }^{208} \mathrm{~Pb} /{ }^{204} \mathrm{~Pb}$ and ${ }^{207} \mathrm{~Pb} /{ }^{204} \mathrm{~Pb}$ versus ${ }^{206} \mathrm{~Pb} /{ }^{204} \mathrm{~Pb}$ diagrams (Figure 10) is that the sediments at the basal edge of the profiles are generally aligned with the pelagic sediment line and indicate little or no interaction with the MORBs. 


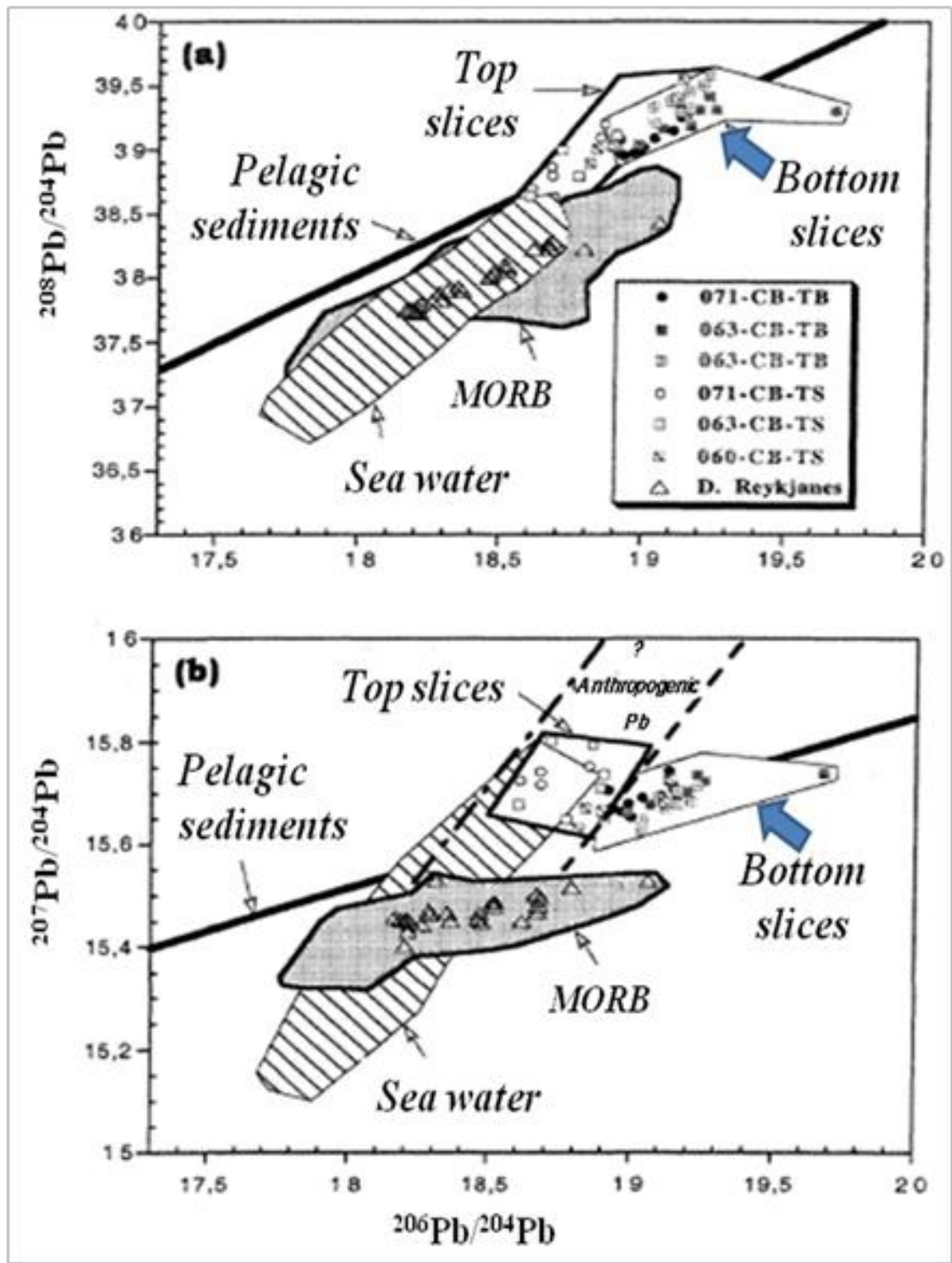

Figure 10: Diagrams ${ }^{208} \mathrm{~Pb} /{ }^{204} \mathrm{~Pb}$ (a) and ${ }^{207} \mathrm{~Pb} /{ }^{204} \mathrm{~Pb}$ (b) versus ${ }^{206} \mathrm{~Pb} /{ }^{204} \mathrm{~Pb}$ of the top and bottom slices of the box-cores. The line in bold appears on the right of the pelagic sediments (Dia Hantchi, 2000). Surface water fields (Véron \& al., 1994) and MORB are shown for comparison purposes. In Figure 10 (b), the two dotted lines are interpreted as the mixing beam involving the top slice samples, the seawater and the MORBs.

If we can say that, as a whole, the isotopic compositions in $\mathrm{Sr}$ and $\mathrm{Nd}$ (Figure 8) do not provide very precise information because of an insufficient number of measurement points, the $\mathrm{Pb}$ isotopes show that these deposits would derive from a mixture of materials from a dominant continental crustal crust where at least two sources with ${ }^{238} \mathrm{U} /{ }^{206} \mathrm{~Pb},{ }^{235} \mathrm{U} /{ }^{207} \mathrm{~Pb}$, and ${ }^{232} \mathrm{Th} /{ }^{208} \mathrm{~Pb}$ ratios 
would be expressed: one at $\mu\left({ }^{238} \mathrm{U} /{ }^{204} \mathrm{~Pb}\right)$ low and the other at $\mu$ relatively higher. The very high value component of $\mu$ would be on the one hand formed by minimal inflows of Baltic origin and on the other hand by the Arctic component, which remains the most dominant (Dia Hantchi, 2000; Figure 9). Along the side inputs of the low $\mu$ component (i.e. depleted in $\mathrm{U}$ ), the southeast Greenland contribution is recorded (e.g. Saunders \& al., 1999; Figure 9). In this regard (the control of terrigenous sediment supplies and leading to a gradient), a general link with the Nordic seas seems reasonable. Therefore, as point out by Våge \& al. (2011), that gradient depends mainly on the vigor of the North Icelandic Jet (NIJ) advection overflow water into the Denmark Strait.

(iii) By comparison, the slices of sediments define a band in which samples (including leachates-duplicates; Figure 10) are distributed between seawater poles and MORB. Recall that in $\mathrm{Pb} / \mathrm{Pb}$ diagrams [Figures 10 (a) and 10 (b)], the mixtures of the different components define straight lines (not curves) that are independent of the concentration. Ornately, it is impossible to make a detailed calculation in terms of balance sheet, because we do not have the $\mathrm{Pb}$ contents of each sample. However, it is possible to say that at least $20 \%$ of the lead is anthropogenic, if we limit ourselves to a simple two-component mixture (Figure 10b). These data confirm the observations of Véron $\&$ al. (1994) who estimate that 10 to $40 \%$ of the lead contained in particles carried by the surface waters of basins north of the $50^{\text {th }}$ parallel would be associated with the NAD (Figure 1). While the gasoline $\mathrm{Pb}$-bearing aerosols went into decline (Shotyk \& al., 2003), other sources of anthropogenic Pb (as coalburning and high-temperature industrial activities) were quantitatively more important in world oceans (Echegoyen \& al., 2014). Similarly, it should be noted that the sediments of $071 \mathrm{BC}$ and $063 \mathrm{BC}$, which are supposed to be the closest to the mantle pole (i.e. the pole more depleted in ${ }^{206} \mathrm{~Pb}$ and ${ }^{207} \mathrm{~Pb}$ ), remain the most influenced by the seawater pole (Figure 10b). This could be related to the internal structure of much more stratified water columns west of the Reykjanes Ridge than in the east flank and over the crest (Lucotte \& Hillaire-Marcel, 1994). The stratification of the water masses intervenes here in the direction of mechanical mixing and thus the possibilities of homogenization. We emphasize that "the magnitude of $\mathrm{Pb}$ disturbance is much more pronounced in surface waters than in intermediate and deep waters" (Lambert \& al., 1991). Such an interpretation is supported by a more vigorous interaction and vertical mixing between water and terrigenous elements (and so anthropogenic contributions) in the eastern basins (e.g. Ferron $\&$ al. 2014). Futhermore, the good stratification of the waters west of the ridge would tend to favor the more lateral detrital inputs related to the deepest body of water (e.g. García-Ibáñez \& al. 2018) before the flows coming from the surface or 
judged here moderately advected (Daniault $\&$ al., 2016). This suggestion is in agreement with the fact that lower $\varepsilon_{\mathrm{Nd}}(0)$ [circa-10] is found in the sediments of the box-core 060BC taken from the west flank, a ridge region that characterized by detrital elements with Greenlandic-Arctic signature. That fits remarkably well with Van de Flierdt \& al. (2016), who noted that "in the western North Atlantic, Nd isotopes generally follow patterns of advection, as do Al concentrations". It follows that the $\mathrm{Pb}$ tracer is "superior" to $\mathrm{Nd}$ isotopes "in depicting water mass mixing and vertical cycling in the eastern North Atlantic basins".

\section{Conclusion}

In this paper we bring out several aspects of the North Atlantic Ocean sediments composition, through a comparison with radiogenic isotopes signatures. Specific areas of interest are the hydrodynamics of the currents bordering and crossing the Reykjanes Ridge, the structure of water masses and pollutants distribution, and the features of sedimentary load source inside the large-scale circulation. The bicompartmental model of the radiogenic isotopes distribution, that we established on pelagic sediments, is particularly well applied here. Basal portions of the profiles are interpreted as reflecting mixtures of materials derived almost from the eastern Greenland margins, the Arctic seas and the Baltic Shield. Uppermost portions of the profiles are under the influence of mixed sources including the Icelandic and Reykjanes Ridge basalts and the overlying water masses. These later are, in turn, affected by airborne anthropogenic pollution transported from North America and Europe continents. The coupling between the dominant Arctic pole, and the differentiated elements of Iceland and the Reykjanes Ridge is a key of observation indicating that the North Icelandic Jet (NIJ) is ultimately the source of most of the water in the deep Irminger Sea. The Reykjanes Ridge's topography has a great influence on currents, and the axial ridge tectonic segmentation is a feature that might partly guide the NEADW into the Irminger Sea, where it can mix with the composite waters of the DSOW. Zonal differences in the $\mathrm{Pb}$ 's isotopic compositions of the uppermost sequence portions are both large magnitude. Thus spatial coherence makes it likely that real water spatial structure and/or water-mass transformation are indicative of the width of the pollutants vertical distribution. The isotopic characterization of the predominant effects of water structuring in higher horizons still possible. However, more sequences with high spatial and temporal resolution should be studied in order to recover useful data to provide detailed information on the current and sedimentary regimes, as well as the physiographic context. 


\section{References:}

1. Amano,Y., Kuwahara, M., Takahashi, T., Shirai, K., Yamane, K., Amakawa, H. \& Otake, O. (2013). Otolith elemental and Sr isotopic composition as a natal tag for Biwa salmon Oncorhynchus masou sub sp. in Lake Biwa, Japan. Aquatic Biology, 19, 85-95. doi: 10.3354/ab00520.

2. Artale, V., Falcini, F., Marullo, S., Bensi, M., Kokoszka, F., Iudicone, D. \& Rubino, A. (2018). Linking mixing processes and climate variability to the heat content distribution of the Eastern Mediterranean abyss. Scientific Reports, 8 (11317), 1-10. doi: 0.1038/s41598-01829343-4.

3. Bashmachnikov, I., Nascimento, Â., Neves, F., Menezes, T. \& Koldunov, N.V. (2015). Distribution of intermediate water masses in the subtropical northeast Atlantic. Ocean Science, 11, 803-827.

4. Buckley, M.W. \& John Marshall, J. (2016). Observations, inferences, and mechanisms of the Atlantic Meridional Overturning Circulation: A review. Reviews of Geophysics, 54, 5-63. doi:10.1002/2015RG000493.

5. Chafik, L., Rossby, T., \& C. Schrum, C. (2014). On the spatial structure and temporal variability of poleward transport between Scotland and Greenland. Journal of Geophysical Research: Oceans, 119, 824-841. doi:10.1002/2013JC009287.

6. Courtene-Jones, W., Quinn, B., Gary, S.F., Mogg, A.O.M. \& Narayanaswamy, B.E. (2017). Microplastic pollution identified in deep-sea water and ingested by benthic invertebrates in the Rockall Trough, North Atlantic Ocean. Environmental Pollution, 231, 271280.

7. Curry, R. \& Mauritzen, C. (2005). Dilution of the Northern North Atlantic Ocean in Recent Decades. Science, 308, 1772-1774.

8. Daniault, N., Mercier, H., Lherminier, P., Sarafanov, A., Falina, A., Zunino, Z., Pérez, F.F., Ríos, A.F., Ferron, B., Huck, T., Thierry, V. \& Gladyshev, S. (2016). The northern North Atlantic Ocean mean circulation in the early $21^{\text {st }}$ century. Progress in Oceanography, 146, 142-158.

9. DeMets, C., Gordon, R.G., \& Argus, D.F. (2010). Geologically current plate motions. Geophysical Journal International, 181 (1), 1-80. http://doi.org/10.1111/j.1365-246X.2009.04491.

10. DePaolo, D.J. (1988). Neodymium isotope geochemistry. An introduction. Berlin: Springer-Verlag, $187 \mathrm{p}$.

11. Dia Hantchi, K. (2000). Géochimie isotopique (Sr-Nd-Pb) des sédiments accumulés depuis 700000 ans le long de la dorsale de 
Reykjanes $\left(58-60^{\circ}\right.$ Nord). Ph.D. Thesis. Université du Québec à Montréal, Canada, $219 \mathrm{p}$.

12. Echegoyen,Y., Boyle, E.A., Lee, J.M., Gamo, T., Obata, H. \& Norisuye, K. (2014). Recent distribution of lead in the Indian Ocean reflects the impact of regional emissions. In PNAS: 15328-15331, 111 (43). www.pnas.org/cgi/doi/10.1073/pnas.1417370111.

13. Elders, W.A. \& Friðleifsson, G.Ó. (2015). Investigating a Mid-Ocean Ridge Hydrothermal System on Land: the Iceland Deep Drilling Project on the Reykjanes Peninsula in SW Iceland. In Proceedings World Geothermal Congress 19-25 April 2015, Paper 14018: Melbourne, Australia, $9 \mathrm{p}$.

http://iddp.is/wp-content/uploads/2015/04/2-paper-4-37002-WAEand-GOF.pdf

14. Eldevik, T. \& Nilsen, J.E.Ø. (2013). The Arctic-Atlantic Thermohaline Circulation. Journal of climate, 26, 8698-8705.

15. Fagel, N., Innocent, C., Gariépy, C. \& Hillaire-Marcel, C. (2002). Sources of Labrador Sea sediments since the last glacial maximum inferred from Nd-Pb isotopes. Geochimica et Cosmochimica Acta, 66 (14), 2569-2581.

16. Fagel, N., Not, C., Gueibe, J., Mattielli, N. \& Bazhenova, E. (2014). Late Quaternary evolution of sediment provenances in the Central Arctic Ocean: mineral assemblage, trace element composition and $\mathrm{Nd}$ and $\mathrm{Pb}$ isotope fingerprints of detrital fraction from the Northern Mendeleev Ridge. Quaternary Science Reviews, 92, 140-154.

17. Ferron, B., Kokoszka, F., Mercier, H. \& Lherminier, P. (2014). Dissipation Rate Estimates from Microstructure and Finescale Internal Wave Observations along the A25 Greenland-Portugal OVIDE Line. Journal of Atmospheric and Oceanic Technology, 31, 2530-2543.

18. Frank, M. (2002). Radiogenic isotopes: Tracers of past ocean circulation and erosional input. Reviews of Geophysics, 40 (1), 87551209/02/2000RG000094.

19. García-Ibáñez, M.I., Pérez, F.F., Lherminier, P., Zunino, P., Mercier, H. \& Tréguer, P. (2018). Water mass distributions and transports for the 2014 GEOVIDE cruise in the North Atlantic. Biogeosciences, 15, 2075-2090.

20. Goldstein, S.L. \& Hemming, S.R. (2003). Long-lived Isotopic Tracers in Oceanography, Paleoceanography, and Ice-sheet Dynamics, Treatise on Geochemistry, 6, 453-489. 
21. Homoky, W.B., Weber, T., Berelson, W.M., Conway,T.M., Henderson, G.M., van Hulten, M., Jeandel, C., Severmann, S. \& Tagliabue, A. (2016). Quantifying trace element and isotope fluxes at the ocean-sediment boundary: a review. Phil. Trans. R. Soc. A 374: 20160246. http://dx.doi.org/10.1098/rsta.2016.0246.

22. Hudson, A. (2017). Réduire la pollution marine. http://www.undp.org/content/undp/fr/home/blog/2017/3/7/The-wayforward-for-reducing-marine-pollution.html.

23. Ionov, D.A., Mukasa, S.B. \& Bodinier, J.L. (2002). Sr-Nd-Pb Isotopic compositions of peridotite xenoliths from Spitsbergen: Numerical modelling indicates $\mathrm{Sr}-\mathrm{Nd}-\mathrm{Pb}$ by melt percolation metasomatism. Journal of Petrology, 43 (12), 2261-2278.

24. Kanzow, T. \& Zenk, W. (2014). Structure and transport of the Iceland Scotland Overflow plume along the Reykjanes Ridge in the Iceland Basin. Deep-Sea Research I, 86, 82-93.

25. Kirillova, V. (2017). Radiogenic isotopes on marine sediments from the Baffin Bay: implications for the sediment supply during the last deglaciation. Ph.D. Thesis. Universität Bremen, Germany, 188 p.

26. Kokfelt, T.F., Hoernle, K., Hauff, F., Fiebig, J., Werner, R. \& GarbeSchönberg, D. (2006). Combined Trace Element and $\mathrm{Pb}-\mathrm{Nd}-\mathrm{Sr}-\mathrm{O}$ Isotope Evidence for Recycled Oceanic Crust (Upper and Lower) in the Iceland Mantle Plume. Journal of Petrology, 47 (9), 1705-1749.

27. Kuhlbrodt, T., Griesel, A., Montoya, M., Levermann, A., Hofmann, M. \& Rahmstorf, S. (2007). On the driving processes of the Atlantic meridional overturning circulation, Reviews of Geophysics, 45, RG2001, 32 p. doi:10.1029/2004RG000166.

28. Lacan, F. \& Jeandel, C. (2005). Acquisition of the neodymium isotopic composition of the North Atlantic Deep Water, Geochemistry Geophysics Geosystems, 6, Q12008, 20 p. doi:10.1029/2005GC000956.

29. Lackschewitz, K.S., Endler, R., Gehrke, B., Wallrabe, H.-J. \& ThiedeH, J. (1996). Evidence for topography-and current-controlled deposition on the Reykjanes Ridge between $59^{\circ} \mathrm{N}$ and $60^{\circ} \mathrm{N}$. DeepSea Research I, 43, 1683-1711.

30. Lambert, C.E., Véron, A., Buat-Ménard, P., Heyraud, M., Grousset, F. \& Simpson, W. (1991). The role of large biogenic particles in the transport of atmospheric pollutant $\mathrm{Pb}$ down to North Atlantic sediments. Oceanologica Acta, 14 (1), 67-76.

31. Lucotte, M. \& Hillaire-Marcel, C. (1994). Identification des grandes masses d'eau dans les mers du Labrador et d'Irminger. Revue canadienne des sciences de la Terre, 31, 1-4. 
32. Magde, L.S. \& Smith, D.K. (1995). Seamount volcanism at the Reykjanes Ridge : relationship to the Iceland hot spot. Journal of Geophysical Research, 100 (B5), 8449-8468.

33. Manighetti, B. (2001). Lessons of the past. Ocean circulation: the planet's great heat engine. Water \& Atmosphere, 9 (4), 12-13. NIWA, Wellington.

34. Munk, W. \& Wunsch, C. (1998). Abyssal recipes II: energetics of tidal and wind mixing. Deep-Sea Research I, 45, 1977-2010.

35. Racapé, V., Zunino, P., Mercier, H., Lherminier, P., Bopp, L., Pérèz, F.F. \& Gehlen, M. (2018). Transport and storage of anthropogenic C in the North Atlantic Subpolar Ocean. Biogeosciences, 15, 4661-4682.

36. Rahmstorf, S. (2006). Thermohaline Ocean Circulation. In Elias, S.A. (Ed.), Encyclopedia of Quaternary Sciences, Amsterdam: Elsevier, pp. $1-10$.

37. Rattinacannou, J.E. (2011). Un nouveau courant marin découvert au nord-est de 1'Islande. http://www.futura sciences.com/planete/ actualites/climatologie-nouveau-courant-marin-decouvert-nordislande-33036.

38. Rocha, R.D.M.F. (2017). Bathymetry of the Southern Reykjanes Ridge and Changes in Seafloor Topography between 1996 and 2013. Master Thesis. University of Iceland, Iceland, $153 \mathrm{p}$.

39. Rosman, K.J.R., Chisholm, W., Boutron, C.F., Candelone, J.P., Jaffrezo, J.L., \& Davidson, C.I. (1998). Seasonal variations in the origin of lead in snow at Dye 3, Greenland. Earth and Planetary Science Letters, 160 (3-4), 383-389.

40. Sarafanov, A., Falina, A., Mercier, H., Sokov,A., Lherminier, P., Gourcuff, C., Gladyshev, S., Gaillard, F. \& Daniault, N. (2012). Mean full-depth summer circulation and transports at the northern periphery of the Atlantic Ocean in the 2000s. Journal of Geophysical Research, 117, C01014, 22 p. doi:10.1029/2011JC007572.

41. Savkina, K.E., Bashirova, L.D. \& Novichkova, E.A. (2018). Changes in surface conditions east of the ReykjanesRidge (North Atlantic) during the Late Pleistocene to Holocene cold events, Russian Journal of Earth Sciences, 18 (4), ES5004, 38 p. doi:10.2205/2018ES000634.

42. Saunders, A.D., Kempton, P.D., Fitton, J.G. \& Larsen, L.M. (1999). $\mathrm{Sr}, \mathrm{Nd}$, and $\mathrm{Pb}$ isotpes and trace element geochemistry of basalts from the Southeast Greenland margin. In Larsen, H.C., Duncan, R.A., Allan, J.F., Brooks, K. (Eds.), Proceedings of the Ocean Drilling Program, Scientific Results : Vol. 163. College Station (Texas): Ocean Drilling Program, pp. 77-92. 
43. Shorttle, O., Maclennan, J. \& Piotrowski, A.M. (2013). Geochemical provincialism in the Iceland plume. Geochimica et Cosmochimica Acta, 122, 363-397.

44. Shotyk., W., Goodsite, M.E., Roos-Barraclough, F., Frei, R., Heinemeier, J. Asmund, G., Lohse, C. \& Hansen, T.S. (2003). Anthropogenic contributions to atmospheric $\mathrm{Hg}, \mathrm{Pb}$ and $\mathrm{As}$ accumulation recorded by peat cores from southern Greenland and Denmark dated using the ${ }^{14} \mathrm{C}$ "bomb pulse curve". Geochimica et Cosmochimica Acta, 67 (21), 3991-4011.

45. Simon, Q. (2007). Analyse sédimentologique et isotopique ( $N d \& P b)$ d'une carotte sédimentaire prélevée dans le Détroit du Danemark (MD99-2322). Implication sur l'évolution de la circulation océanique profonde au cours de l'Holocène. Master Thesis, Université de Liège, Belgique, $92 \mathrm{p}$.

46. Sutton, J.N., de Souza, G.F., García-Ibáñez, M.I. \& De La Rocha, C.L. (2018). The silicon stable isotope distribution along the GEOVIDE section of the North Atlantic Ocean. The silicon stable isotope distribution along the GEOVIDE section (GEOTRACES GA-01) of the North Atlantic Ocean. Biogeosciences, 15, 5663-5676. https://www.biogeosciences.net/15/5663/2018/bg-15-5663-2018.pdf

47. Talley, L.D. (2002). Ocean Circulation. In MacCracken, M.C. \& Perry, J.S. (eds) (2002) Encyclopedia of Global Environmental Change Vol. 1 The Earth system: Physical and chemical dimensions of global environmental change. Chichester: John Wiley \& Sons, pp. 557-579.

48. Thompson, A.F. \& Rahmstorf, S. (2009). Ocean Circulation. Geophysical Research Series, 187, 99-118.

49. Torsvik, T.H., Amundsen, H.E.F., Trønnes, R.G., Doubrovine, P.V., Gaina, C., Kusznir, N.J., Steinberger, B., Corfu, F., Ashwal, L.D., Griffin, W.L., Werner, S.C. \& Jamtveit, B. (2015). Continental crust beneath southeast Iceland. In PNAS 2015. 112 (15): E1818-E1827. https://www.ncbi.nlm.nih.gov/pmc/articles/PMC4403175/pdf/pnas.20 1423099.pdf

50. Våge, K., Pickart, R.S., Spall, M.A., Valdimarsson, H., Jónsson, S., Torres, D.J., Østerhus, S. \& Eldevik, T. (2011). Significant role of the North Icelandic Jet in the formation of Denmark Strait overflow water. Nature Geoscience, 4, 723-727.

51. Van Cauwenberghe, L., Vanreusel, A., Mees, J. \& Janssen, C.R. (2013). Microplastic pollution in deep-sea sediments. Environmental Pollution, 182, 495-499. 
52. Van de Flierdt,T., Griffiths, A.M., Lambelet, M., Little, S.H., Stichel, T. \& Wilson, D.J. (2016). Neodymium in the oceans: a global database, a regional comparison and implications for palaeoceanographic research. Phil.Trans.R.Soc. A374:20150293, 30 p. https://pdfs.semanticscholar.org/4c3a/8042cd8ce51a736e61a574a 82d1e1aa27bc9.pdf

53. Véron, A., Church, T.M., Patterson, C.C. \& Flegal, A.R. (1994). Use of stable lead isotopes to characterize the sources of anthropogenic lead in North Atlantic surface waters. Geochimica et Cosmochimica Acta, 58, 3199-3206.

54. Xu, X., Rhines, P.B., Chassignet, E.P. \& Schmitz Jr., W.J. (2015). Spreading of Denmark Strait Overflow Water in the Western Subpolar North Atlantic: Insights from Eddy-Resolving Simulations with a Passive Tracer. Journal of Physical Oceanography, 45, 2913-2932. doi: 10.1175/jpo-d-14-0179.1.

55. Zeng, F., Liang, M., Peng, S., Yu, D. \& Xiang, S. (2015). Sr-Nd-Pb Isotopic Compositions of the Neogene Eolian Deposits in the Xining Basin and Implications for Their Dust Sources. Journal of Earth Science, 26 (5), 669-676. ISSN 1674-487X. Printed in China. doi: $10.1007 / \mathrm{s} 12583-015-0575-2$. 